\title{
Review \\ Orchestrated Cytokines Mediated by Biologics in Psoriasis and Its Mechanisms of Action
}

\author{
Aina Akmal Mohd Noor ${ }^{1}$, Maryam Azlan ${ }^{2}(\mathbb{D})$ and Norhanani Mohd Redzwan ${ }^{1, *}$ \\ 1 Immunology Department, School of Medical Sciences, Universiti Sains Malaysia, \\ Kubang Kerian 16150, Kelantan, Malaysia; ainaakmal@student.usm.my \\ 2 School of Health Sciences, Universiti Sains Malaysia, Kubang Kerian 16150, Kelantan, Malaysia; \\ maryamazlan@usm.my \\ * Correspondence: hanani.redzwan@usm.my; Tel.: +60-9767-6130
}

check for updates

Citation: Mohd Noor, A.A.; Azlan, M.; Mohd Redzwan, N. Orchestrated Cytokines Mediated by Biologics in Psoriasis and Its Mechanisms of Action. Biomedicines 2022, 10, 498 . https://doi.org/10.3390/ biomedicines 10020498

Academic Editor: Giuseppe Murdaca

Received: 25 January 2022

Accepted: 14 February 2022

Published: 20 February 2022

Publisher's Note: MDPI stays neutral with regard to jurisdictional claims in published maps and institutional affiliations.

Copyright: (C) 2022 by the authors. Licensee MDPI, Basel, Switzerland. This article is an open access article distributed under the terms and conditions of the Creative Commons Attribution (CC BY) license (https:// creativecommons.org/licenses/by/ $4.0 /)$.

\begin{abstract}
Psoriasis is an autoimmune disease mediated by disturbed T cells and other immune cells, and is defined by deep-red, well-demarcated skin lesions. Due to its varied etiologies and indefinite standard pathogenesis, it is challenging to consider the right treatment exclusively for each psoriasis patient; thus, researchers yearn to seek even more precise treatments other than topical treatment and systemic therapy. Using biologics to target specific immune components, such as upregulated cytokines secreted by activated immune cells, is the most advanced therapy for psoriasis to date. By inhibiting the appropriate pro-inflammatory cytokines, cellular signaling can be altered and, thus, can inhibit further downstream inflammatory pathways. Herein, the roles of cytokines with their mechanisms of action in progressing psoriasis and how the usage of biologics alleviates cellular inflammation are discussed. In addition, other potential pro-inflammatory cytokines, with their mechanism of action, are presented herein. The authors hope that this gathered information may benefit future research in expanding the discovery of targeted psoriasis therapy.
\end{abstract}

Keywords: psoriasis; biologics; inhibitors; cytokines; immune cells; autoimmune disease

\section{Introduction}

Psoriasis is a chronic autoimmune disease characterized by significant dermal lesions caused by disturbed immune cells [1]. As reported by the National Psoriasis Foundation [2], psoriasis is quite prevalent and affects approximately 125 million people, which constitutes $2-3 \%$ of the global population, with no sexual bias [3,4]. Psoriasis is often associated with genetic predisposing disease, in which one-third of the global cases were initiated during childhood rather than due to exogenous triggers, such as skin trauma and chemical irritants $[5,6]$. The most common clinical observation for psoriasis is the well-demarcated inflamed lesions which usually appear with red and/or white scaly patches that often have silver patches [7]. Apart from the physical burden, psoriasis often affects social well-being as well as causing emotional and psychological stress $[7,8]$. Generally, there are varying types of psoriasis, for instance, plaque psoriasis, guttate psoriasis, erythrodermic psoriasis, pustular psoriasis and others, such as palmoplantar, nail and hair psoriasis. All these types are the results of impaired immune cell connections, especially within the integumentary layers, and are caused by some triggers [9].

These interrupted immune components lead to turmoiled T cells signaling and eventually trigger the keratinocytes on the epidermis layers to become hyperproliferative. Psoriasis patients experience fast skin replacement on the affected area due to truncated keratinocytes within just three to five days, where normal skin replacement is about 28 days [10]. Most of the lesions are associated with a deep-red colorization that comes with visible blood capillaries and/or dense erythema patterns on the psoriatic skin [11]. This is due to the intensified neovascularization which occurs because of the highly promoted angiogenesis activity that acts via angiogenic mediators. These mediators aid in 
forming numerous cellular infiltrations at the lesioned site [10,12]. With all the unique clinical observations, the Psoriasis Area and Severity Index (PASI) scoring system was created to guide the standardization of psoriatic lesions, and comprises three main parameters: erythema, skin thickness and scale formation $[13,14]$.

All conditions stated above are the outcomes of pathophysiology for all types of psoriasis. However, to date, the benchmark of psoriasis pathogenesis is yet to be discovered, since the current understanding relies on hypothesizes relating to multifactorial etiologies $[15,16]$. Mapping the complete circuit of the psoriasis cellular pathogenesis framework is, therefore, a significant technological challenge. Understanding the complete psoriasis pathogenesis would be of great benefit for establishing ultimate treatments, since the chronic nature of psoriasis often leads to future relapse, hence requiring a long-term treatment instead [6]. Nonetheless, psoriasis is, indeed, caused by the chaos of triggered immune cells and its cytokines, such as tumor necrosis factor (TNF)- $\alpha$, interleukin (IL)-17, IL-22, IL-23, and granulocyte-macrophage colony-stimulating factor (GM-CFS) that flare up throughout the pathway [17]. It was found that due to this cytokine storm episode, psoriasis patients are vastly vulnerable to comorbid diseases, such as psoriasis arthritis, Crohn's disease, malignancy and even cardiovascular disease, which are mostly life-threatening [18-20]. Hence, the highlighted point here is the uncontrolled production of cytokines in regard to psoriasis would lead to various immune cells signaling in a chain reaction fashion, which leads to hyperproliferative keratinocytes and potentially excessive antimicrobial peptides (AMP), such as LL-37 [21,22].

\section{Pathogenesis of Psoriasis}

The sustained inflammation that leads to uncontrolled keratinocyte proliferation and faulty differentiation are the hallmarks of psoriasis. Multiple triggers could be from exogenous sources, for instance, infection, skin trauma, smoking habits, drugs, infections and occupational hazards [5]. A strong familial hereditary association of psoriasis-susceptible loci PSORS is also a cause of severe psoriasis development which can be detected at an early age $[23,24]$. If the disease is considered to be acquired, it might be from certain intrinsic conditions, such as hypertension, diabetes mellitus and predisposing metabolic syndrome [5,25].

Indeed, the complete pathogenesis of psoriasis remains ambiguous, and the "Psoriatic Universe" is still indefinite and waiting to be fully explored [26]. The development of psoriasis can be divided into four main phases: triggered initiation, responsive innate immune response, stimulated adaptive immune response and excessive epidermal proliferation (Figure 1). It is highly suggested that nucleic acid complexes, such as AMP chains of cathelicidin LL-37 within the upper layer of the skin, stimulate plasmacytoid dendritic cells (pDCs) during the early onset of psoriasis. Plasmacytoid DCs produce cytokines such as IFN- $\gamma$, TNF- $\alpha$, IL-12 and IL-23 to communicate with myeloid dendritic cells (mDCs). These cytokines then signal $\mathrm{CD}^{+}$and $\mathrm{CD}^{+} \mathrm{T}$ cells to undergo clonal expansion and produce IL-17 and IL-22. CD8 ${ }^{+} \mathrm{T}$ cells migrate and connect with the MHC I receptors of the keratinocytes to assemble chemoattractants and innate immune mediators [27]. Moreover, mDCs also stimulate the differentiation of Thelper (Th)1, Th22 and Th17 cells. Th1 cells secrete IFN- $\gamma$, TNF- $\alpha$ and IL- 2 which promotes the inflammatory factors by signaling keratinocytes and DCs. Conversely, Th22 cells produce IL-22, which is responsible for triggering keratinocyte-derived $\mathrm{T}$ cell-recruiting chemokines and gives rise to the changed dermal phenotype, comprising epidermal hyperplasia, acanthosis and parakeratosis. Th17 cells that are stimulated by IL-1, IL-23, IL-12 and TNF- $\alpha$ release IL-17 once they undergo migration towards the dermis $[28,29]$. The released IL-17 then signals the keratinocytes to express TNF- $\alpha$ and CC chemokine ligands (CCL20). The combination of IL-17 and TNF- $\alpha$ can assemble neutrophils and create Munro's microabscesses. Neutrophils can undergo degranulation and produce granular compounds, such as neutrophil elastase (NE), proteinase 3, LL-37, reactive oxygen species (ROS), $\alpha$-defensin with antimicrobial characteristics and lipocalin, as well as C-X-C-motif ligand (CXCL)8, IL-6 and CCL20 [30]. 


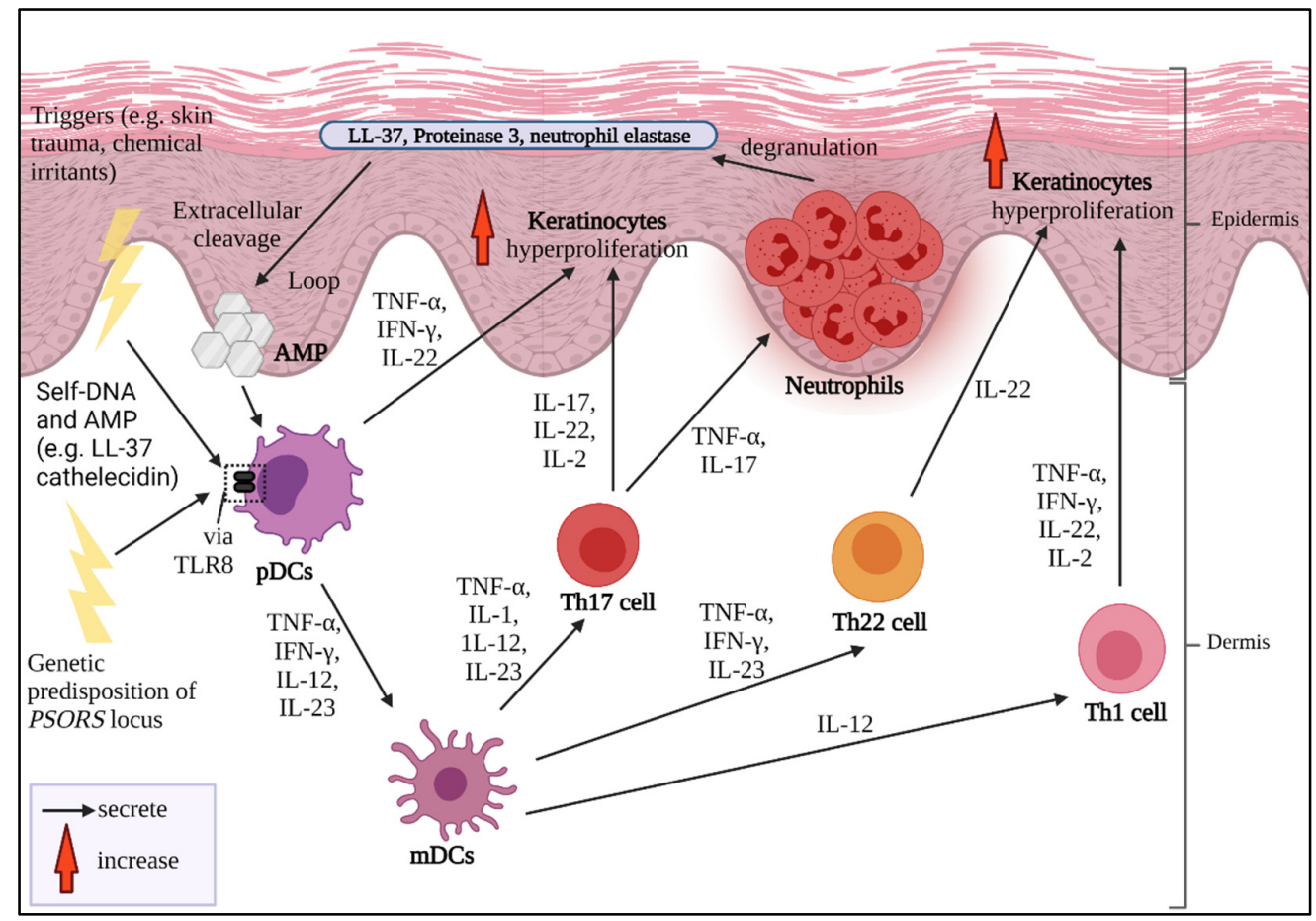

Figure 1. The summarized pathogenesis of psoriasis. Upon triggers, pDCs receive the signal via TLR8 and present the antigens to mDCs. mDCs activate Th1 and Th22 cells to release cytokines to generate hyperproliferative keratinocytes in the epidermis region. mDCs also present cytokines to Th17 cells to initiate keratinocyte hyperproliferation and the assembling of neutrophils to create Munro's microabscesses. It is thought that once neutrophils undergo degranulation, this produces granular compounds, such as LL-37 and proteinase 3, which create an information loop to be detected again by pDCs. The cycle repeats. (AMP: antimicrobial proteins; PSORS: psoriasis susceptibility loci).

\section{Psoriasis and Cytokines as Biologics Target}

The currently available treatments for psoriasis are topical application, systemic therapy and biologics. Topical application is the only preferred treatment for mild psoriatic lesions and best acts on the surface of the lesioned sites in the short term. Hence, the epidermis layer in which keratinocytes become hyperproliferative can be softened and reduce the uncomfortable signs especially during flare-ups, which include itchy, tingling and burning sensations [5,31].

In tackling the recurrent flaring episodes, particularly in moderate to severe forms, some patients choose systemic therapy, especially when they are unable to respond well to topical application. However, the long-term administration of systemic therapy results in low acceptance and potential multiorgan failure, as well as probable skin carcinogenesis [5,32]. For example, methotrexate disturbs DNA synthesis, replication and reconstruction. Some systemic therapies, for instance, acitretin and cyclosporin, lead to the abnormality of liver function and subsequent dyslipidemia, hyperkalemia, hyperuricemia and hypomagnesemia [33].

Biologics are considered to be the most advanced treatment strategy with minimum risks. It is very beneficial for moderate-to-severe psoriasis patients, since this drug can selectively inhibit and/or dissolve targeted cytokines, hence reducing further inflammatory pathways [34,35]. Biologics are made of large and complex elements of combined monoclonal antibodies $(\mathrm{mAb})$ with receptor fusion proteins which function to target immune mediators specifically [33]. They can specifically block any designated cytokines and their receptors from regulating the downstream signaling pathways [36].

The exploration of the usage of biologics has become worldwide after the discovery of the first successful introduction of alefacept, a type of biologic, in psoriasis [37]. This is the first instance of biologics in psoriasis using the dimeric fusion of the extracellular section of 
the human leukocyte function antigen-3 (LFA-3) and the Fc section of immunoglobulin (Ig) G1, which was approved by the US Food and Administration (FDA) in 2004 [38]. Alefacept is a non-cytokine-blocking agent, since it is designed to target the interaction of $\mathrm{T}$ cells by blocking LFA-3 signaling on CD2, thus deactivating the stimulation [38-40]. However, it is indicated that alefacept produces non-neutralizing antibodies [41] and side effects [42]. Hence, further research later yearned to focus more on cytokine inhibitors instead [42].

Cytokines play a massive role in orchestrating and assembling the immune cells in psoriasis; thus, this could be the most suitable target to be used as a promising treatment [18]. The discovery of an effective novel biologic gives new insights into how beneficial it is to target important immune components, such as cytokines, in alleviating psoriasis exasperation. Hence, it can support other advanced methods, such as the quantification of numerous cytokines receptors using both mRNA and cDNA microarrays [43,44]. Thus, it is crucial to inhibit cytokine signaling if that is the attempted exit strategy for psoriasis. Herein, the information of the main cytokine inhibition targets, along with potential cytokines and their mechanism of action in psoriasis, are discussed. A literature search was conducted in PubMed, Scopus, ScienceDirect and Google Scholar using the search terms "psoriasis" AND "biologics" AND ("cytokines" OR "treatment" OR "pathogenesis" OR "pro-inflammatory" OR "topical" OR "systematic" OR "inhibitors" OR "TNF- $\alpha$ " OR "infliximab" OR "etanercept" OR "adalimumab" OR "certolizumab" OR "pegol" OR "IL-17" OR "secukinumab" OR "ixekizumab" OR "brodalumab" OR “IL-23" OR “tildrakizumab" OR "guselkumab" OR "risankizumab" OR "IL-12/23" OR "ustekinumab" OR "IFN" or "interferon" OR "IL-1" OR “IL-36" OR "IL-6" OR "IL-8" OR “IL-21" OR “IL-17/23" OR “IL-22").

\section{Main Potential Cytokine Targets in Psoriasis}

Herein, the profiles of the main cytokines that play a major role in psoriasis are summarized and discussed.

\subsection{TNF- $\alpha$ Inhibitors}

TNF- $\alpha$ is a proinflammatory cytokine secreted by DCs, T cells, macrophages and nonimmune cells, such as fibroblasts; therefore, its selection in the revolution of inhibitor drugs is promising [44]. TNF- $\alpha$ acts as the main mediator during the initiation phase of classical psoriasis and can sustain the disease over the long term [45-47]. It interposes inflammatory cascades, promotes cell growth, neovascularization and apoptosis and regulates the aggregation of other immune cells to the site of the lesions [12]. TNF- $\alpha$ plays an important role in suppressing the regulatory $\mathrm{T}$ cells, preventing them from allowing the subsequent hyperproliferation of pathogenic T cells and IL-17-producing cells. As a result, IL-17 is unable to stimulate $\mathrm{CD} 8^{+} \mathrm{T}$ cells; instead, it is downregulated $[48,49]$. Hence, the serum level of TNF- $\alpha$ in psoriatic patients is highly elevated with a positive correlation with the PASI score. Since TNF- $\alpha$ is also considered to be the central cytokine in this autoimmune disease, it can give predictions of the exacerbation susceptibility of psoriasis. Psoriasis can, indeed, be inherited and run down the family tree; hence, by tracing TNFA genes on the short arm of chromosome 6, which comprises $-238 \mathrm{G}>\mathrm{A},-380 \mathrm{G}>\mathrm{A}$ and $-875 \mathrm{C}>\mathrm{T}$, genetic polymorphism as the predisposing factor could give early insights and help to identify drug targets $[50,51]$. Studies have reported that these polymorphisms contribute to more than $50 \%$ of prevalence cases in psoriasis [ $43,44,52,53]$. Moreover, TNF- $\alpha$, as the homotrimer cytokine, is associated with altering the cell cycle, especially in keratinocytes and hair follicles in psoriasis [54]. Collectively, these findings suggest that TNF- $\alpha$ is, indeed, a good candidate with which to establish a specific treatment regime for psoriasis.

During the early onset of psoriasis, DCs release TNF- $\alpha$ along with other cytokines, such as IL-23, to signal for the assembling of $\mathrm{CD}^{+}$and $\mathrm{CD}^{+} \mathrm{T}$ cells. Eventually, T cells migrate to the upper layer of the skin, which is near the epidermis region [55]. Since this disease involves the concurrent activity of multiple cytokines, TNF- $\alpha$ works best when combined with IL-17A and IL-17C $[30,56]$. The combination produces a preferable 
synergistic induction to generate chains of $\mathrm{T}$ cell expression [12]. For instance, TNF- $\alpha$ steadily integrates with IL-17A mRNA to upregulate IL-17A signaling and simultaneously initiates the overexpression of IL-17R on keratinocytes, causing them to become hyperproliferative $[30,57]$. TNF- $\alpha$ can also trigger DCs to release IL-23, stimulating Th17 cells. Concomitantly, keratinocytes are triggered by both TNF- $\alpha$ and cytokines from stimulated Th17 cells, causing them to undergo proliferation and produce chemokines [58].

In conjunction, anti-TNF- $\alpha$ biologics, such as etanercept, infliximab, adalimumab and golimumab, as illustrated in Figure 2, function to target and prevent the TNF- $\alpha$ in the inflammatory environment from stimulating other immune components. The function of TNF- $\alpha$ inhibitors differs from their respective molecular structure [59]. For example, etanercept is a type of psoriasis biologic that is made up of a large dimeric protein fusion of the extracellular region of TNFR2 fused with the Fc section of the humanized IgG1 mAb. It can capture the soluble and non-membrane-bound circulatory TNF- $\alpha$, preventing it from binding to its receptors or TNF- $\alpha$ trimers, regardless of a weak binding $[60,61]$. It has been reported that etanercept is well tolerable in psoriasis patients, including pediatric and geriatric groups, for up to four years of treatment [62].

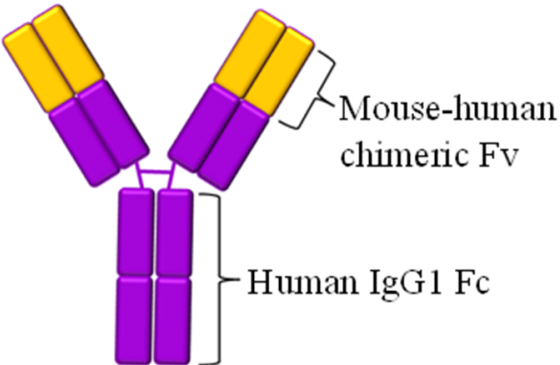

Infliximab



Adalimumab

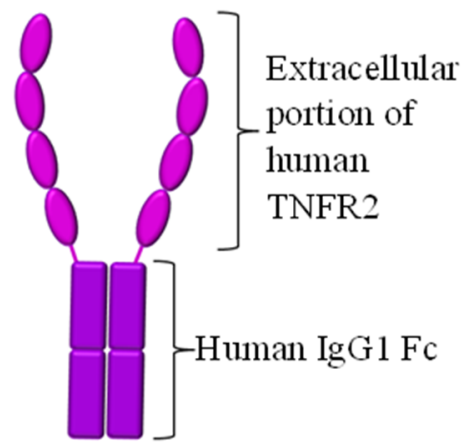

Etaner cept

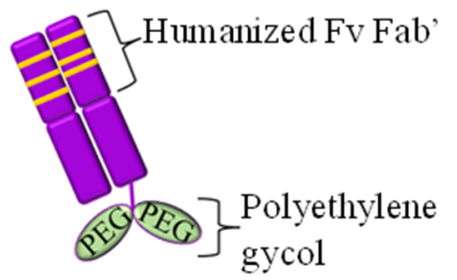

Cer tolizumab pegol

Figure 2. TNF- $\alpha$ inhibitors. Infliximab and adalimumab depict almost similar molecular structures with different Fv regions. Etanercept has specialized extracellular portions of human TNFR2. Certolizumab pegol is the most unique, as its Fc region is replaced with PEG molecules to lengthen its half-life.

Meanwhile, infliximab and adalimumab share almost the same structures, but have different constituents. Infliximab is a chimeric, with $75 \%$ of it made up of a human IgG1 original section and $25 \%$ made up of a murine-derived antigen-binding variable section [63]. It is highly specific, whereby it can only neutralize the biological activity of TNF- $\alpha$ compared to TNF- $\beta$, although these two cytokines exhibit quite similar molecular structures [64]. Infliximab binds with a high affinity towards the circulating and transmembrane-bound 
TNF- $\alpha$. Therefore, TNF- $\alpha$ will be inhibited from binding to its receptors and cellular lysis, which generates TNF- $\alpha$, will also be prevented $[65,66]$. It can be concluded that infliximab can suppress any TNF- $\alpha$-mediated connecting cascades of cellular proliferation and programmed cell death [67]. A collective of evidence stated that psoriasis patients who received a long-term subcutaneous injection of infliximab in their treatment regime experienced improved skin lesions and other related health conditions, such as psoriasis arthritis [68].

Although the molecular structures of adalimumab are almost similar to infliximab, it is not structurally chimeric, since it is made up of fully IgG1 human mAb, similar to golimumab [65,69]. Adalimumab is suitable for moderate-to-severe psoriasis patients in long-term treatment [70]. Its mechanism of action is also similar to infliximab. Nevertheless, infliximab is superior to adalimumab, since adalimumab is not highly specific when compared to the other two. This is due to the various binding affinities of adalimumab towards different antibody-antigen interfaces, whereby the force is lower than infliximab [65]. Blocking the free-bound and trans-membranous TNF- $\alpha$ in psoriasis from binding to a TNFR2 receptor can neutralize this overproduced cytokine. Hence, the downstream TNF- $\alpha$ signaling pathways that play a role in exacerbating psoriasis can be inhibited/blocked [51].

Meanwhile, on a side note, golimumab is better to administer in psoriatic arthritis patients instead of other psoriasis types [71]. Since golimumab has a high affinity and specificity towards TNF- $\alpha$, it works well in blocking TNF- $\alpha$ from interacting with its receptor, hence neutralizing its downstream bioactivity. These bioactivities include neutralizing TNF- $\alpha$-induced cell surface expression to block the adhesion activities of E-selectin, vascular cells and human endothelial cells [72]. To achieve $50 \%$ neutralization, golimumab requires less concentration when compared to infliximab and adalimumab, a property which is similar to etanercept. Golimumab is not exclusively used for psoriasis; however, it is the only FDA-approved psoriasis arthritis and rheumatoid arthritis drug/treatment [73].

In addition, among these listed TNF- $\alpha$ inhibitors, infliximab is the most efficient drug/inhibitor compared to adalimumab, golimumab and etanercept, given its high affinity and a PASI score that decreases by at least 75\% after its administration [74]. Inhibiting the overproduced TNF- $\alpha$ in severe cases of psoriasis using different inhibitors opens many discussions relating to how different clinical efficacies can result in its improved biological activities. These drugs stated herein are only the primary example, since their usage is quite common.

Another TNF- $\alpha$-blocking agent which has recently been discussed and explored is certolizumab pegol. It is an Fc-free with polyethylene glycol (PEG) biologic with chemical structures that are often described as peculiar since it has no Fc region. Due to its uniqueness, it disables the binding with the neonatal Fc receptor for IgG ( $F \subset R n$ ) and, hence, minimizes the placental transfer from mother to the fetus [75]. Moreover, the PEG structure allows certolizumab pegol to undergo PEGylation to lengthen its half-life by up to 14 days [76]. Certolizumab pegol is not intensively discussed concerning psoriasis since it is commonly administered for rheumatoid arthritis [77]. This biologic is FDA-approved for psoriatic arthritis; hence, it is still yet to be exclusive solely for psoriasis. Nevertheless, this drug potentiates an excellent efficacy in improving psoriasis and has an acceptable safety profile [78].

\subsection{IL-17 Inhibitors}

IL-17 is also a promising inhibitory target in psoriasis. This inflammatory cytokine is generally involved in inflammatory cascades and reconstructing the outer cellular barrier. IL-17 is rather unique since it has multiple significant families which share homology properties, such as almost similar molecular structures $[79,80]$. To date, the most explored IL-17 additional families are IL-17A, IL-7B, IL-17C, IL-17D, IL-17E and IL-17F [81-84]. A previous study has shown that some of these cytokines undergo a prominent, differed expression in skin-manifested diseases, including psoriasis. In psoriasis, with the presence of IL- 6 and transforming growth factor- $\beta, C D 4^{+} T$ cells will undergo differentiation into 
Th17. This event will lead to the secretion of proinflammatory cytokines, including IL17 [85]. In a general understanding pertaining to psoriasis, IL-17 leads to the elevated expression of proinflammatory factors as well as promoting NF- $\mathrm{kB}$ and mitogen-activated protein kinase (MAPK) pathways [86]. IL-17 is also the key mediator in neovascularization, endothelial irregularities and coagulation, which leads to thrombosis, as well as arterial hypertension. This is one of the reasons why psoriasis is often correlated with cardiac dysfunctionality $[87,88]$.

Among these listed additional families, IL-17A stands out the most as playing the central role in autoimmune diseases, followed by IL-17C and IL-17F [89,90]. By referring and comparing them to IL-17A in terms of the proteomic degree of conservation, we find that IL-17F has the most similarities at 55\%, while IL-17E depicts the least similarities at $16 \%$ [91]. Nevertheless, in regard to autoimmunity and chronic inflammatory diseases, IL-17A, IL-17C and IL-17F act as the key mediators in manipulating the pathway cellular machinery $[79,90,92,93]$.

In psoriasis, IL-17A directly enhances keratinocyte gene expression, such as that of cathelicidin (LL-37) antimicrobial peptides [94], via its target receptors, IL-17RA and IL-17RC [95]. During the early onset of psoriasis, LL-37 initiates the immune pathway, which eventually activates T cell-expressing IL-17A subsets, such as Th17 cells. These Th17 cells release several cytokines, including IL-17A and IL-17F, as the inflammatory biomarkers to quickly render keratinocyte hyperproliferative $[96,97]$. The released IL-17A further aggregates neutrophils and simultaneously inhibits the apoptosis mechanism of neutrophils and elicits neovascularization by assisting the angiogenesis pathway [98,99]. Since IL-17A has a rather stabilized mRNA, it can also work synergistically with TNF- $\alpha$ to exacerbate cytokine storming and the overexpression of keratinocytes $[30,100]$. The investigation of serum IL-17A in psoriasis patients revealed the increment of IL-17A, indicating a more highly lesioned microenvironment [101-105].

IL-17A is the pillar foundation of other additional IL-17 families as it is the main key effector cytokine in regard to IL-17. IL-17F shares half of its homologous form with IL-17A, although IL-17A is thought to be more potent than IL-17F $[95,106]$. The latest findings relating to IL-17F in psoriasis depict a quite ambiguous role, but show that it still may be the effector of IL-6 production, which is the pro-inflammatory cytokine entailing inflammation [107]. IL-17F-altered expression leads to intensified psoriatic skin inflammation, as proven in both preclinical and clinical findings [19,108-110].

On another note, IL-17C, which is a rather more newly discovered IL-17 family mostly affecting keratinocytes, is $23 \%$ homologous with IL-17A and can connect to its own $[80,110]$. Structurally, the composition of the IL-17C receptor includes IL-17RE, which has the highest level of specificity of those specialized to IL-17C [56]. In a preclinical investigation of psoriasis, IL-17C was found to be highly upregulated and was suspected to largely contribute to the formation of psoriatic dermatitis in mice [104]. Some clinical findings suggested that IL-17C intensifies the plaque formation on psoriatic skin biopsies, whereby IL-17C is overexpressed up to 125 times more than IL-17A [56,110-112]. Herein, the discussion is focused on IL-17A, IL-17C and IL-17F, since these families mediate autoimmunity the best, albeit in the presence of other additional families. In addition to IL-17A being the main driver in mediating inflammation, this cytokine is locally overproduced at the psoriatic lesioned area; hence, tackling it in order to neutralize or stop its overproduction is a great idea to ameliorate painful flaring patches [113]. This discovery opens up numerous discussions on the inhibition of IL-17 as one of the strategies for alleviating psoriasis inflammation with biologic drugs.

Secukinumab is a type of biologic drug, approved by the FDA in 2015, constructed from a recombinant human $\mathrm{mAb}$ of IgG1, and which can selectively bind to IL-17A and IL17F [114]. This drug is suitable to treat moderate-to-severe plaque psoriasis, hypertrophic palmoplantar psoriasis, generalized pustular psoriasis and active psoriatic arthritis in adult patients [115]. When all conditions (no hypersensitivity contracted, pass the tuberculosis initial evaluation and not taking live vaccine injections) are met, secukinumab serves as 
the first-line biologic therapy when patients experience intolerability and are approaching the possibility of multi-organ failure after systemic therapy administration [116]. The mechanism of action of secukinumab in psoriasis focuses on targeting the IL-17A released from Th17 to block it from binding with IL-17R. Thus, antimicrobial peptides and the subsequently released cytokines, such as IL-17A and IL-17F, can also be reduced and blocked [117]. The successful blocking of IL-17A from proceeding with the signaling cascade leads to benefits, such as lowering keratinocyte hyperproliferation, preventing $\mathrm{T}$ cells infiltration and halting the overexpression of pathogenic genes [116]. The administration of secukinumab has shown success in some large randomized, double-blind and placebocontrolled trials. Patients receiving this biologic give positive clinical feedback, especially in relation to relieving palmoplantar and nail psoriasis, as well as plaque psoriasis. Despite potential drawbacks, such as headaches and upper respiratory tract infections, which are are inevitable, psoriatic patients are mostly well adapted to secukinumab administration [114].

Meanwhile, ixekizumab is another IL-17 inhibitory biologic drug. It is a humanized mAb IgG4 with a high affinity to specifically bind to IL-17A [118]. It has been approved by the FDA in 2016 for the treatment of moderate-to-severe plaque psoriasis in adults, and has recently been used as a treatment for psoriatic arthritis as well [119]. The mechanism of action of ixekizumab is similar to that of secukinumab, which involves targeting IL$17 \mathrm{~A}$ in psoriasis pathogenesis. Some studies have suggested that ixekizumab is more efficient than etanercept in downregulating cytokine chaos in psoriasis after just two weeks of administration [94,120]. Indeed, the quality of life in psoriatic patients receiving ixekizumab has been reported to be positive after a good assessment on the Dermatology Life Quality Index (DLQI) simultaneously with an improved PASI score, including the clearing of lesions within one year of the study being conducted [121].

Another IL-17 inhibitor joining the mainstream biologic treatment strategy of psoriasis is brodalumab. Brodalumab is a recombinant, fully humanized mAb IgG2 that was approved by the FDA in 2017 for the treatment of psoriasis vulgaris and pustular psoriasis [122]. This biologic is an interesting one, since it is the first IL-17 inhibitor drug that blocks and neutralizes IL-17 receptors due to its high affinity instead of the IL-17 cytokine itself [123]. After administration, brodalumab binds to IL-17A and IL-17C receptors, IL-17RA and IL-17RC. This action concomitantly blocks IL-17 from binding, thus downregulating psoriatic inflammation, such as lesioned skin transcriptome, and neutralizes associated gene expression. Hence, chemokine and IL-23 production are halted to further reduce psoriatic inflammation [124,125]. Such an impactful mechanism of action in blocking IL17 by blocking IL-17 inhibitors brings benefits to psoriasis patients, including reduced inflammation of lesions and direct improvement in cardiovascular diseases [121,126].

\subsection{IL-23 Inhibitors}

The IL-23 structure has two main subunits, which are p19 and p40, which are specific to IL-23 and IL-12/IL-23, respectively. IL-23 is primarily produced by DCs and macrophages, while its receptors are commonly expressed on T cells, NK cells, neutrophils, macrophages and mast cells. With the presence of TNF- $\alpha$, IFN- $\gamma$ and other transcription factors, IL-23 can further enhance its regulation via the TLR signaling pathway [127]. In terms of its mechanism of action, IL-23 firstly binds to its receptor to form an IL-23/IL-23R complex. This can initiate Th17, Th22, $\mathrm{CD}^{+}, \mathrm{CD}^{+}$and $\gamma \delta \mathrm{T}$ cells to produce pro-inflammatory cytokines, such as IL-17 and IL-22, which play roles in inflammatory pathways and neovascularization [124,128]. If IL-17A is absent in the event, IL-23 will stimulate keratinocytes, making them become hyperproliferative. Other mechanisms of IL-23 include triggering the proliferation of macrophages to generate more TNF- $\alpha$ and amplifying IL-23R expression to form a self-amplifying loop [128,129]. These events, in which IL-23 is overexpressed, are devastating in immune-mediated diseases, such as psoriasis, especially since there is evidence of upregulated IL-23 in psoriatic lesions $[128,130]$. Therefore, IL-23 does play a significant role in the pathogenesis of psoriasis from the early onset to its sustenance 
mechanisms $[122,131]$. The advanced technology of using biologics in inhibiting IL-23 in psoriasis has succeeded, giving promising results [132].

Tildrakizumab is a fully human mAb of IgG1 kappa suitable for adults who have moderate-to-severe psoriasis. It was approved by the FDA in 2018 and has a high affinity for selecting the p19 subunit of IL-23 [133]. Due to this characteristic, tildrakizumab will bind to this subunit, causing the later event of cytokine signaling to be prohibited. Hence, other downstream pro-inflammatory mediators will also be halted [134]. Tildrakizumab is more effective than TNF- $\alpha$ inhibitors, such as etanercept, as it is proven to achieve PASI 75 on the 12th week of administration [135].

Tildrakizumab's mechanism of action is similar to other IL-23 inhibitors, such as guselkumab and risankizumab. Both biologics are a fully human $\mathrm{mAb}$ of IgG1, approved by the FDA for moderate-to-severe plaque psoriasis in adult patients [122,136]. These drugs are considered in mainstream biologics, since they are proven to lower the overexpressed IL-6, IL-17A, IL-17F and IL-22 as early as four weeks before the administration. This is concurrent with the reduced discomfort signs and symptoms of psoriasis as well [137].

\subsection{IL-12/23 Inhibitors}

IL-12 belongs to the heterodimeric cytokine IL-6 superfamily and has a structural $\beta$-chain subunit of p40 similar to IL-23; the only difference is in its $\alpha$-chain, which commonly comprises a p35 instead [138]. Commonly, IL-12 is produced by DCs, macrophages, monocytes and B cells. In terms of biological activities, IL-12 and IL-23 primarily contribute to the expansion of Th1 and Th17 cells, respectively. In psoriasis, the common p40 subunit is the succeeding key that binds to its receptor to form its complex formation. Early investigations in both preclinical and clinical studies have shown that the p40 subunit of these pro-inflammatory cytokines is overexpressed $[129,139]$. This is necessary for the subsequent immunoregulation for recruiting pro-inflammatory Th1 and Th17 cells and triggering the release of their associated pro-stimulatory cytokines [140].

Most $\mathrm{CD}^{+} \mathrm{T}$ cells express IL-12 and its subunits, such as IL-12R $\beta 2$ and IL-12p40, which further initiate the differentiation of $\mathrm{T}$ cells via Toll-like receptor signaling. This event will consequently overproduce IFN- $\gamma$ [141]. Meanwhile, IL-23 can bind to IL-23R to initiate the secretion of multiple cytokines, such as IL-17, IL-22, IL-26, IFN- $\gamma$ and TNF- $\alpha$, as well as CCL20 [142]. Through the combination of the signal transducer and activator of transcription (STAT) 3 and RAR-related orphan receptor gamma (ROR $\gamma \mathrm{t}$ ) working together, IL-23 and IL-23R can transactivate to harmonize a positive feed-forward loop to reinforce IL-23R, IL-17 and IL-22 expressions. Eventually, the Th17 phenotype can achieve its stabilization, which is required for sustaining cytokine secretion, including IL-17 for keratinocyte hyperproliferation $[142,143]$. All these events are aggravated by the $\mathrm{p} 40$ subunit of both IL-12 and IL-23. Thus, p40 serves as the most favored target to inhibit the downregulation of the overall biological activities of IL-12 and IL-23, especially in psoriasis [140,142,143].

Ustekinumab is the only sole prime IL-12/23 inhibitor to date. It is a humanized $\mathrm{mAb}$ IgG1 $\kappa$, and can bind to the p40 subunit of both IL-12 and IL-23 and disturb the downstream immunoregulation. It is suitable to administer to moderate-to-severe psoriasis patients due to its efficacy profiling $[140,144]$. The efficacy of ustekinumab in psoriasis can be seen by comparing mRNA expression alteration using microarray analysis. Concurrent with more than $75 \%$ PASI score amelioration, this IL-12/23p40 inhibitor caused a significant difference in approximately 5000 of the genes modulated. As a result, TNF- $\alpha$ is suppressed due to the successful blocking of IL-12/23, which provides subsequent IL-17-associated gene downregulation. In comparison with etanercept, ustekinumab excels in suppressing multivariate psoriasis-associated genes and cytokines such as IL-1, IL-22, IFN- $\gamma$ and IL-17. Although it is unfortunate to learn that ustekinumab does not have enough data to support long-term usage, this dual-functioning inhibitor is proven to enhance the quality of life in psoriatic patients [145-147]. The cytokine inhibitors used in psoriasis treatment are summarized in Table 1, and the simplified mode of action of all inhibitors are illustrated in Figure 3. 
Table 1. Summary of cytokine inhibitors used in psoriasis treatment.

\begin{tabular}{|c|c|c|c|c|c|c|}
\hline $\begin{array}{l}\text { Cytokine } \\
\text { Targets }\end{array}$ & $\begin{array}{l}\text { Biologic Drug } \\
\text { Name (Brand) }\end{array}$ & $\begin{array}{l}\text { Year of FDA } \\
\text { Approval for } \\
\text { Psoriasis } \\
\text { Treatment }\end{array}$ & $\begin{array}{l}\text { Molecular } \\
\text { Structure }\end{array}$ & Mode of Action & Possible Side Effects & References \\
\hline \multirow{5}{*}{ TNF- $\alpha$} & $\begin{array}{c}\text { Infliximab } \\
\left(\text { Remicade }^{\circledR}\right)\end{array}$ & 2006 & $\begin{array}{l}\text { Human-mouse } \\
\text { chimeric } \\
\text { combination of } \\
\text { mAb IgG1 }\end{array}$ & $\begin{array}{l}\text { Inhibit circulating } \\
\text { and } \\
\text { transmembrane- } \\
\text { bound } \\
\text { TNF- } \alpha\end{array}$ & $\begin{array}{l}\text { Upper respiratory } \\
\text { tract infection, } \\
\text { hepatotoxicity, } \\
\text { tuberculosis risk, } \\
\text { worsening psoriasis }\end{array}$ & {$[63,65,66]$} \\
\hline & $\begin{array}{l}\text { Etanercept } \\
\left(\text { Enbrel }^{\circledR}\right)\end{array}$ & 2004 & $\begin{array}{l}\text { Extracellular } \\
\text { region of TNFR2 } \\
\text { fusion with } \\
\text { humanized } \\
\text { mAb IgG1 }\end{array}$ & $\begin{array}{c}\text { Inhibit soluble } \\
\text { and } \\
\text { non-membrane- } \\
\text { bound circulatory } \\
\text { TNF- } \alpha \text { from } \\
\text { binding to TNFR2 } \\
\text { receptor }\end{array}$ & $\begin{array}{l}\text { Upper and lower } \\
\text { respiratory tract } \\
\text { infections, rhinitis, } \\
\text { pharyngitis, } \\
\text { tuberculosis risk }\end{array}$ & {$[60,61]$} \\
\hline & $\begin{array}{l}\text { Adalimumab } \\
\left.\text { (Humira }{ }^{\circledR}\right)\end{array}$ & 2008 & $\begin{array}{l}\text { Humanized } \\
\text { mAb IgG1 }\end{array}$ & $\begin{array}{l}\text { Inhibit circulating } \\
\text { and } \\
\text { transmembrane- } \\
\text { bound } \\
\text { TNF- } \alpha\end{array}$ & $\begin{array}{l}\text { Upper respiratory } \\
\text { tract infection, } \\
\text { sinusitis, urinary } \\
\text { tract infection }\end{array}$ & {$[64,69]$} \\
\hline & $\begin{array}{l}\text { Golimumab } \\
\left(\text { Simponi }{ }^{\circledR}\right)\end{array}$ & Not applicable * & $\begin{array}{l}\text { Humanized } \\
\text { mAb IgG1k }\end{array}$ & $\begin{array}{l}\text { Inhibit circulating } \\
\text { and } \\
\text { transmembrane- } \\
\text { bound } \\
\text { TNF- } \alpha\end{array}$ & $\begin{array}{c}\text { Recurring } \\
\text { psoriasis flare }\end{array}$ & {$[72]$} \\
\hline & $\begin{array}{c}\text { Certolizumab } \\
\text { pegol }\left(\text { Cimzia }^{\circledR}\right)\end{array}$ & Not applicable * & $\begin{array}{l}\text { Humanized Fab } \\
\text { subunit to } \mathrm{mAb} \\
\text { fusion, with } \\
\text { Fc-free } \\
\text { PEGylation and } \\
\text { no Fc region }\end{array}$ & $\begin{array}{l}\text { Inhibit circulating } \\
\text { and } \\
\text { transmembrane- } \\
\text { bound } \\
\text { TNF- } \alpha\end{array}$ & $\begin{array}{l}\text { Urinary tract } \\
\text { infections, } \\
\text { gastroenteritis, } \\
\text { nasopharyngitis, } \\
\text { headache, pruritus, } \\
\text { tuberculosis risk }\end{array}$ & [75] \\
\hline \multirow{3}{*}{ IL-17 } & $\begin{array}{l}\text { Secukinumab } \\
\left(\text { Cosenty }{ }^{\circledR}\right)\end{array}$ & 2015 & $\begin{array}{l}\text { Humanized } \\
\text { mAb IgG1 }\end{array}$ & $\begin{array}{l}\text { Inhibit IL-17A } \\
\text { and IL-17F }\end{array}$ & $\begin{array}{c}\text { Nasopharyngitis, } \\
\text { diarrhea, } \\
\text { mucocutaneous } \\
\text { candidiasis, upper } \\
\text { respiratory tract } \\
\text { infection, neutropenia }\end{array}$ & {$[114,117]$} \\
\hline & $\begin{array}{l}\text { Ixekizumab } \\
\quad\left(\text { Taltz }^{\circledR}\right)\end{array}$ & 2016 & $\begin{array}{l}\text { Humanized } \\
\text { mAb IgG4 }\end{array}$ & Inhibit IL-17A & $\begin{array}{l}\text { Candidiasis, irritable } \\
\text { bowel syndrome, } \\
\text { neutropenia }\end{array}$ & [118] \\
\hline & $\begin{array}{l}\text { Brodalumab } \\
\quad\left(\text { Siliq }^{\circledR}\right)\end{array}$ & 2017 & $\begin{array}{l}\text { Humanized } \\
\text { mAb IgG2 }\end{array}$ & $\begin{array}{l}\text { Block IL-17A and } \\
\text { IL-17C receptors }\end{array}$ & $\begin{array}{l}\text { Arthralgia, headaches, } \\
\text { fatigue }\end{array}$ & {$[122,124,125]$} \\
\hline \multirow{3}{*}{ IL-23 } & $\begin{array}{l}\text { Tildrakizumab } \\
\left.\text { (Ilumya }^{\circledR}\right)\end{array}$ & 2018 & $\begin{array}{l}\text { Humanized } \\
\text { mAb IgG1k }\end{array}$ & $\begin{array}{l}\text { Inhibit IL-23 } \\
\text { alpha subunit; } \\
\text { p19 subunit }\end{array}$ & $\begin{array}{l}\text { Inflammatory bowel } \\
\text { syndrome, acute } \\
\text { myocardial infarction }\end{array}$ & {$[122,136]$} \\
\hline & $\begin{array}{l}\text { Guselkumab } \\
\left(\text { Tremfya }{ }^{\circledR}\right)\end{array}$ & 2017 & $\begin{array}{l}\text { Humanized } \\
\mathrm{mAb} \operatorname{IgG} 1 \lambda\end{array}$ & $\begin{array}{l}\text { Inhibit IL-23 } \\
\text { alpha subunit; } \\
\text { p19 subunit }\end{array}$ & $\begin{array}{l}\text { Upper respiratory } \\
\text { tract, nasopharyngitis, } \\
\text { headaches, infection }\end{array}$ & {$[122,136]$} \\
\hline & $\begin{array}{l}\text { Risankizumab } \\
\left(\mathrm{Skyrizi}^{\circledR}\right)\end{array}$ & 2019 & $\begin{array}{l}\text { Humanized } \\
\text { mAb IgG1 }\end{array}$ & Inhibit IL-23A & $\begin{array}{l}\text { Nasopharyngitis, } \\
\text { upper respiratory } \\
\text { tract infection, } \\
\text { headache, } \\
\text { arthralgia, back } \\
\text { pain, diarrhea }\end{array}$ & {$[122,136]$} \\
\hline IL-12/23 & $\begin{array}{l}\text { Ustekinumab } \\
\left(\text { Stelara }{ }^{\circledR}\right)\end{array}$ & 2009 & $\begin{array}{l}\text { Humanized } \\
\text { mAb IgG1 }\end{array}$ & $\begin{array}{l}\text { Simultaneously } \\
\text { inhibit p40 } \\
\text { subunit of IL-12 } \\
\text { and IL-23 }\end{array}$ & Tuberculosis risk & {$[140,145]$} \\
\hline
\end{tabular}




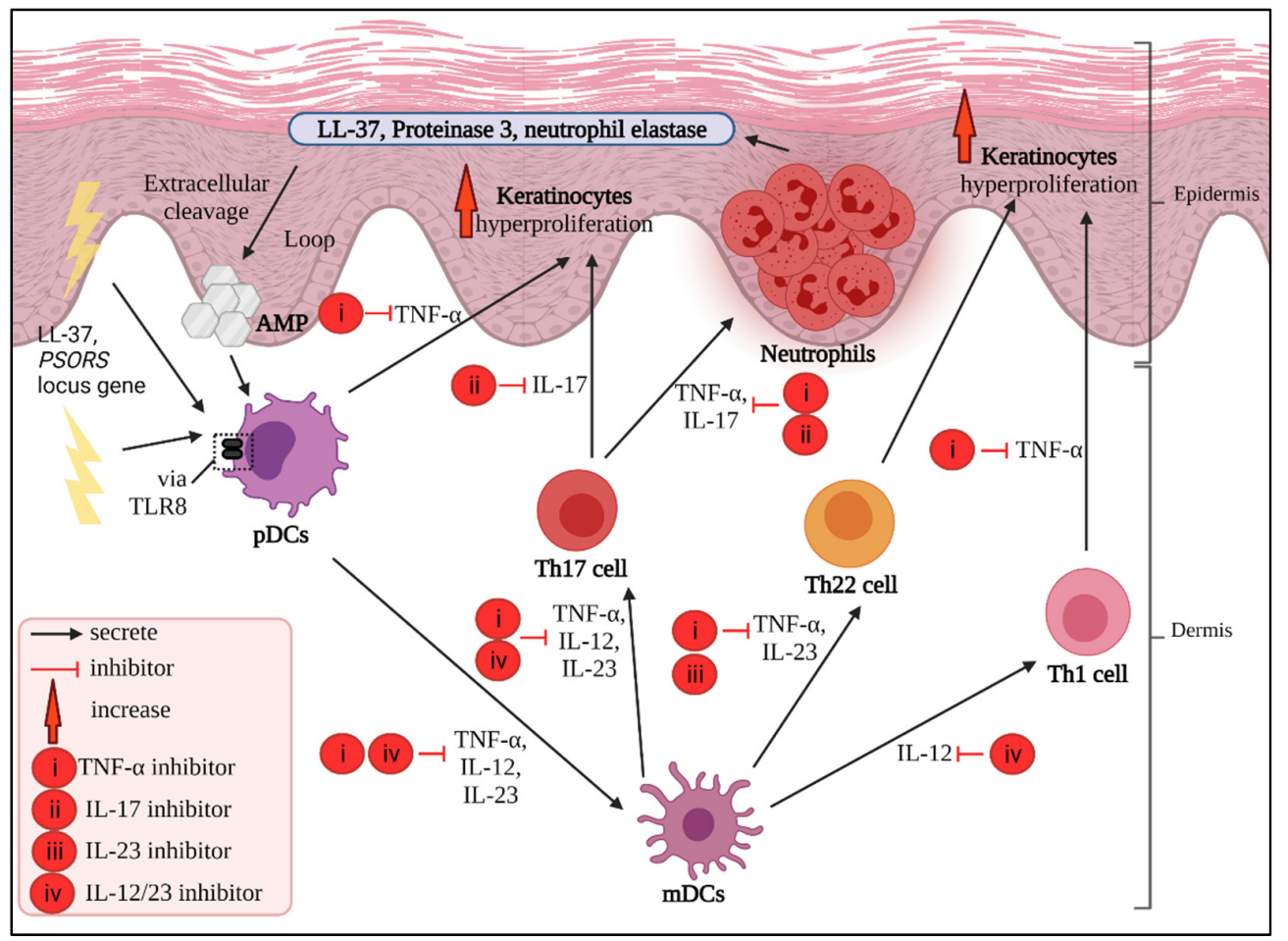

Figure 3. Cytokine inhibitors and their respective blocking interests based on the postulated psoriasis pathogenesis. The overexpressed cytokines released by respective cells can be blocked, and this can downregulate the further inflammatory pathway.

\section{Other Pro-Inflammatory Cytokines Candidates}

From the understanding of the stated cytokines, which provides excellent ideas and a framework for establishing biologics, perhaps other cytokines may render similar benefits in alleviating psoriasis. In immune-mediated inflammatory diseases, pro-inflammatory cytokines are being produced to create an exacerbated inflammatory environment. Herein, other potential cytokines are briefly described in relation to their association with psoriasis and insights into the advantages of targeting them as a treatment plan.

The IFN group is proposed to be beneficial if it is targeted during the early onset of psoriasis progression, especially for paradoxical psoriasis. Type I IFN (IFN- $\alpha$ and $-\beta$ ) is mainly secreted by $\mathrm{pDCs}$ and keratinocytes, which are responsible for recognizing psoriasis autoantigens, such as LL-37 peptides, through TLR-7. It helps in pDC maturation and helps T cells to secrete cytokines such as IL-22, which is necessary for STAT3 phosphorylation and keratinocyte rapid division [147]. Plasmacytoid DC infiltration during this preliminary stage is inevitable, as it is an early response to the skin injury and/or due to the presence of autoantigens. The secretion of Type I IFN can be sustained to further progress the psoriatic inflammation until it enters the adaptive immune response activation phase. Thus, this explains the reason why Type I IFN is absent in chronic psoriatic lesions $[148,149]$. In regard to sustained Type I IFN production, it has also been postulated that blocking TNF may prolong Type I IFN production [150]. Blocking Type I IFNs may inhibit T cells from continuing to develop psoriasis, as reported in an in vivo experiment by Gui and team [151]. Since the presence of this cytokine is significant in the pre-psoriasis microenvironment, perhaps future research may innovate some topical treatments, revised phototherapy regimes or even biologics that can inhibit localized Type I IFN, hence preventing downstream inflammatory regulation.

Similarly, the high level of Type 2 IFN also aids T cells in migration towards the inflammation site, and hypothetically acts as an important linker between inflammatory $\mathrm{T}$ cells and keratinocytes [152]. Earlier data suggested that all clinical types of psoriasis, namely, plague, erythrodermic and guttate, concluded a significant positive correlation 
between PASI score and high levels of IFN- $\gamma$ [153]. The role of IFN- $\gamma$ in psoriasis vulgaris remains to be discovered, since there is no relationship between highly elevated IFN- $\gamma$ with both the mean values of IFN- $\gamma$ and PASI score [154]. Other previous findings are in an agreement with this different pattern; elevated IFN- $\gamma$ may or may not correlate with the PASI score [155]. The disparity of findings suggested that IFN- $\gamma$ may play a role in psoriasis pathogenesis, but this is somewhat ambiguous; therefore, it is not considered to be the definite regulator or a single player in the overall pathways $[153,154]$. Nevertheless, it still contributes to the psoriasis cytokine storm; hence, other postulations suggested that IFN- $\gamma$ is synergic with TNF- $\alpha$. Using transcriptome analysis, these cytokines are found to be a part of a similar process in psoriasis and atherosclerosis when it comes to mediating inflammation. Both cytokines are elevated in moderate-to-severe psoriasis and atherosclerotic plague formation [156]. This idea brings us back to the previous statement that psoriasis is closely related to cardiovascular disease as its comorbidity $[87,88]$. Therefore, instead of IFN- $\gamma$ alone, future research may want to further explore this IFN$\gamma /$ TNF- $\alpha$ synergism, which possibly can establish an ultimate inhibitor for both cytokines at one time.

In IL-1, especially the IL- $1 \beta$ cytokine family, which is secreted by macrophages, DCs and keratinocytes are known to play a role in mediating psoriatic inflammatory pathways, including the sustained production of LL-37 peptides $[157,158]$. This cytokine can initiate the productivity of IL-17 for $\gamma \delta$ T cell differentiation and activation and the further secretion of chemokines. In psoriasis, the significant elevation of IL- $1 \beta$ mRNA and its protein expression level has been observed in the affected skin of psoriasis patients [159]. The same elevation pattern is also observed for IL-36, the IL-1 subfamily in psoriasis [160]. It is known that IL-36 is one of the factors to produce LL-37 peptides by stimulating keratinocytes and activating antigen-presenting cells [161]. IL-36 is also the mediator in angiogenesis and forming Munro's microabscesses. Macrophages that are stimulated by IL-36 can contribute to the increased levels of IL-23 and TNF- $\alpha$ [162]. With all the data gathered, targeting IL-1 and its subfamily, IL-36, in psoriasis can potentially halt inflammatory pathways intracellularly.

IL-6 is one of the most significant cytokines to be intensively elevated by DCs, Th17 cells and even keratinocytes during psoriasis flare, since it plays a major role in mediating inflammation. With the help of IL-6, cells such as DCs, macrophages and keratinocytes can expand their growth and, hence, increase the production of other cytokines. IL-6 is also required in the differentiation phase of Th17 cells and for endothelial cells to express their adhesion parts. IL- 6 can be the targeted target as well, since it engages in some cross-talks with the IL-23/Th17 axis, which is thought to have a substantial role in psoriatic inflammation [163]. Targeting IL-6 has led to promising results in slowing down these uncontrolled biological activities in exacerbating psoriatic lesions, and even in reducing atherosclerosis risk comorbidity [164].

In psoriasis, elevated levels of IL-8 are known to promote keratinocytes to exponentially grow in multiple layers and stimulate neutrophil aggregation. Angiogenesis can be even more advanced with the help of IL-8, thus explaining why psoriasis patients have a greater risk of cardiovascular comorbidity $[10,165,166]$. Targeting the increasing abundance of IL-8 in psoriasis patients may help to prevent these events from happening [167].

The same strategy of halting the elevated pro-inflammatory cytokine in psoriasis may work with IL-21, which is majorly secreted by $\mathrm{CD}^{+} \mathrm{T}$ cells, Th17 cells and $\mathrm{T}$ follicular helper cells [168]. The elevated overall IL-21 secreted by CD4 ${ }^{+} \mathrm{T}$ cells and Th17 cells in the serum of psoriasis patients is significantly correlated with a progressive PASI score. In the same experiment, IL-21 is proven to mediate the differentiation of $\mathrm{CD} 4^{+} \mathrm{T}$ cells to Th17 cells, which has been shown by other similar findings, in addition to the downregulation of Treg cells $[169,170]$. Moreover, IL-21 induces the proliferation of matured B cells by regulating its class-switching process and helps to increase IL-21 and IL-17A secretion [170,171]. These events can be avoided if IL-21 is blocked, and hence downregulates the excessive productivity of Th17 cells. In regard to said Th17 cells, these cells, aided by transcription 
factor retinoid-related orphan receptor (ROR)- $\gamma \mathrm{t}$ and STAT3 and IL-23 secrete IL-17A, IL-22 and TNF- $\alpha$ (Th17 cytokines) and IL-17 for keratinocyte hyperproliferation [172-174]. The correlation of these stated interleukins has been heavily proposed, and research shows that IL-17 works remarkably well in tandem with IL-23, creating an axis called the IL-17/IL-23 axis pathway [26]. In an intensive review by Liu and team [174], the IL-17/IL-23 axis is found to be the next possible candidate for downregulating skin inflammatory diseases, such as psoriasis. IL-23 functions to promote the proliferation of CD4 ${ }^{+} \mathrm{T}$ cells into Th1 cells and Th17 cells. Perhaps future research can investigate in depth the relationship between IL-17 and IL-23 to innovate a binary inhibitor that can halt both cytokines simultaneously.

IL-22 is a rather interesting one, considering that it is a pleiotropic interleukin in which its pro-inflammatory properties may outdo its anti-inflammatory properties when in an excessive amount. In a healthy condition, the IL-22 expressed by keratinocytes is beneficial for wound healing and tissue repair [175]. During psoriatic flares, cells such as lesional T cells secrete IL-22 for epidermal hyperplasia, but do not engage with keratinocyte proliferation directly $[176,177]$. In psoriatic pediatric patients, IL-22 is found to be at a higher level compared to adult patients, showing that its pathogenesis may slightly differ from adults [6,178]. In later evidence, IL-22 triggers Th17 cells, which are required for keratinocyte divisions [179]. This finding correlates with the presence of elevated IL22 gene promoters during the early age of psoriasis onset [180]. However, IL-22 is still responsible for upregulating psoriasis mostly by collaborating with other immune components. In attempting to suppress IL-22, future research potentially can take an approach of targeting its soluble scavenging receptors instead, which mostly includes the IL-22-binding protein IL22BP and/or IL-22RA2. Focusing on IL-22BP, it has been proven, in an in vivo experiment conducted by Voglis and team [181], that this structure is the mediator in propagating psoriasis inflammation, suggesting that other autoimmune diseases may exhibit a similar process. Using this information, IL-22BP may be one of the best candidates to be inhibited in psoriasis.

The idea of blocking these cytokines as summarized in Table 2 must be aligned with the possible limitations and/or adverse effects, which may worsen psoriasis and create other conditions. To date, the possible risks of these inhibitions are rather inconclusive and incomplete, since most of the clinical trials are still ongoing, and some have even come to termination. The absence of a certain kind of cytokine may be compensated by other cytokines, which may create alternated biological events or idiopathic comorbidities. Blocking dual-functioning and synergistic cytokines may need more data, trials and insights into the overall extended eventuality. It is very important to consider all the potential outcomes, considering that administered inhibitors will be circulating throughout the body and not exclusively on psoriasis lesions only.

Table 2. Potential cytokines of interest to be targeted in psoriasis.

\begin{tabular}{|c|c|c|c|c|}
\hline Cytokines Target & Mode of Action in Psoriasis & $\begin{array}{c}\text { Expected Biological } \\
\text { Inhibitory Activities } \\
\text { in Psoriasis }\end{array}$ & $\begin{array}{c}\text { Expected Side } \\
\text { Effects }\end{array}$ & References \\
\hline $\begin{array}{c}\text { Type I IFN } \\
(-\alpha,-\beta)\end{array}$ & $\begin{array}{l}\text { Induce T cells to produce IL-22 for } \\
\text { keratinocyte proliferation. } \\
\text { Mediate CD8 } 8^{+} \mathrm{T} \text { cells to infiltrate the } \\
\text { dermal area. } \\
\text { Promote B cells to differentiate into } \\
\text { antibody-secreting plasma cells. } \\
\text { - } \\
\text { Activate myeloid dermal DCs to } \\
\text { upregulate co-stimulatory substances } \\
\text { and HLA molecules. } \\
\text { Stimulate cDCs and DCs to secrete } \\
\text { IL-23 for Th/Tc17 polarization. }\end{array}$ & $\begin{array}{l}\text { Blocking pDC and cDC } \\
\text { maturation. } \\
\text { No induction of other } \\
\text { autoimmune cells for } \\
\text { chronic-relapsing } \\
\text { pathogenic condition. } \\
\text { Reduce the initial } \\
\text { inflammatory pathway. }\end{array}$ & $\begin{array}{c}\text { Not yet } \\
\text { documented }\end{array}$ & {$[47,147,182-185]$} \\
\hline
\end{tabular}


Table 2. Cont.

\begin{tabular}{|c|c|c|c|c|}
\hline Cytokines Target & Mode of Action in Psoriasis & $\begin{array}{l}\text { Expected Biological } \\
\text { Inhibitory Activities } \\
\text { in Psoriasis }\end{array}$ & $\begin{array}{l}\text { Expected Side } \\
\text { Effects }\end{array}$ & References \\
\hline Type II IFN $(-\gamma)$ & $\begin{array}{l}\text { - Promote keratinocyte proliferation by } \\
\text { inducing the BCLx protein and } \\
\text { altering other antiapoptotic factors. } \\
\text { Establish intercellular adhesion } \\
\text { molecule } 1 \text { (ICAM-1) and HLA-DR } \\
\text { expressions for immunoregulatory of } \\
\text { T cells. }\end{array}$ & $\begin{array}{l}\text { Reduce the production } \\
\text { of pro-inflammatory } \\
\text { cytokines and mediators. } \\
\text { Reduce lymphocytes } \\
\text { from circulation to } \\
\text { migrate at the } \\
\text { inflammation site. }\end{array}$ & $\begin{array}{c}\text { Not yet } \\
\text { documented }\end{array}$ & {$[154,182,183]$} \\
\hline IL-1 $\beta$ & $\begin{array}{l}\text { Stimulate IL-17 for } \gamma \delta \mathrm{T} \text { cell } \\
\text { proliferation for chemokine secretion. }\end{array}$ & $\begin{array}{l}\text { - } \\
\text { peduce IL-6 and IL-8 } \\
\text { angiogenesis. }\end{array}$ & $\begin{array}{l}\text { Recurring } \\
\text { psoriasis flare }\end{array}$ & {$[159,182,183]$} \\
\hline IL-36 & $\begin{array}{l}\text { Produce LL-37 peptides by } \\
\text { stimulating keratinocytes and } \\
\text { activating antigen-presenting cells. } \\
\text { - Angiogenesis mediator }\end{array}$ & $\begin{array}{l}\text { Suppress macrophages } \\
\text { to secrete IL-23 and } \\
\text { TNF- } \alpha \text {. } \\
\text { Reduce the formation of } \\
\text { Munro's microabscesses. }\end{array}$ & $\begin{array}{c}\text { Not yet } \\
\text { documented }\end{array}$ & {$[161,182]$} \\
\hline IL-6 & $\begin{array}{l}\text { Promote Th17 cells and cause } \\
\text { endothelial cells to differentiate. } \\
\text { - } \quad \text { Angiogenesis mediator. } \\
\text { Stimulate DCs, macrophages and } \\
\text { keratinocytes to secrete cytokines. }\end{array}$ & $\begin{array}{l}\text { Disturb the early } \\
\text { initiation of immune } \\
\text { cells interaction. } \\
\text { Downregulate } \\
\text { angiogenesis. } \\
\text { - Suppress IL-23 secretion } \\
\text { by DCs, macrophages } \\
\text { and keratinocytes. }\end{array}$ & $\begin{array}{c}\text { Inducing psoriasis } \\
\text { onset }\end{array}$ & {$[30,161,182]$} \\
\hline IL-8 & $\begin{array}{l}\text { - } \quad \text { Keratinocyte hyperproliferation. } \\
\text { - } \quad \text { Promote neutrophil aggregation. } \\
\text { Angiogenesis mediator. }\end{array}$ & $\begin{array}{l}\text { - } \\
\text { Meduce the formation of } \\
\text { Munro microabscesses. } \\
\text { Reduce the risk of } \\
\text { cardiovascular } \\
\text { conditions related to } \\
\text { psoriasis. }\end{array}$ & $\begin{array}{l}\text { Irritation, pain, } \\
\text { itch, edema }\end{array}$ & {$[10,161,167,182]$} \\
\hline IL-21 & $\begin{array}{l}\text { Promote CD4 }{ }^{+} \mathrm{T} \text { cells to differentiate } \\
\text { to Th17 cells. } \\
\text { - } \quad \text { Promote B cell proliferation. } \\
\text { - Cause population imbalance of Th17 } \\
\text { and Treg cells. }\end{array}$ & $\begin{array}{l}\text { - } \\
\text { Th17 formation. } \\
\text { Restore the balance of } \\
\text { Th17/Treg cells to } \\
\text { proportion. }\end{array}$ & $\begin{array}{c}\text { Not yet } \\
\text { documented }\end{array}$ & [169-171,182] \\
\hline $\begin{array}{l}\text { IL-17/IL-23 } \\
\text { combination }\end{array}$ & $\begin{array}{l}\text { Increase the production of Th17 } \\
\text { cytokines. } \\
\text { Promote inflammatory signaling } \\
\text { pathways. } \\
\text { - Keratinocyte hyperproliferation. }\end{array}$ & $\begin{array}{l}\text { Restrain the positive } \\
\text { feedback loop of } \\
\text { secreted Th17 cytokines. } \\
\text { Downregulate } \\
\text { keratinocyte } \\
\text { hyperproliferation. }\end{array}$ & $\begin{array}{c}\text { Not yet } \\
\text { documented }\end{array}$ & {$[86,174,182]$} \\
\hline IL-22 & $\begin{array}{l}\text { - Increase epidermal hyperplasia. } \\
\text { - } \quad \text { Mediate Th17 cells for keratinocyte } \\
\text { hyperproliferation. }\end{array}$ & $\begin{array}{l}\text { Downregulate Th17 cells } \\
\text { for hyperproliferation. }\end{array}$ & $\begin{array}{c}\text { Not yet } \\
\text { documented }\end{array}$ & {$[176,177,182]$} \\
\hline
\end{tabular}

\section{Conclusions}

The main potential cytokines listed in this review are the most significantly targeted cytokines that have shown effectiveness in alleviating psoriasis, as previously reported. A rather wide point of view of complex psoriasis pathogenesis must be mapped by connecting each piece of information, which consequently can help to avoid any paradoxical conclusions. By analyzing this gathered information on psoriasis, the authors hope to inspire future researchers to establish new treatment ideas and continue to explore the myriad of cytokine profiling with their numerous biological interactions, even if this is considered to be minute detail. Although cytokine inhibitors seem promising, the data findings still leave some research gaps, especially in terms of long-term impacts, vast globalized clinical data, dosage concern, risks assessment and likely multiple adverse effects. Since these biologics are not personalized, more targets of interest must be experimented with and, hence, encourage the researcher to investigate other potential cytokines as well as their biosimilars. Attempting new strategies for establishing new inhibitors must be 
appropriate with individual cytokine profiling and heavily based on clinical evidence, such as the elevation of serum inspection and PASI scores.

By understanding the fundamental mechanisms of action of each potential cytokine in psoriasis, perhaps the issues, including cytokine compensation drawbacks, dual recognition and synergism, can be tackled, leading to the innovation of more advanced biologic treatments with the minimum side effects possible. Every trial further demonstrates how beneficial it is to inhibit these stated cytokines, and perhaps more novel bioactivities can be discovered in regard to psoriasis. Blocking these cytokines may contribute knowledge for treating refractory psoriasis patients, especially classical psoriasis conditions, simultaneously with an understanding of the inhibitors that alter the relationship with other immune components.

Author Contributions: Conceptualization, N.M.R.; methodology, A.A.M.N. and N.M.R.; investigation, A.A.M.N. and N.M.R.; writing-original draft preparation, A.A.M.N.; writing-review and editing, A.A.M.N., N.M.R. and M.A.; visualization, A.A.M.N. supervision, N.M.R. and M.A. All authors have read and agreed to the published version of the manuscript.

Funding: This study is supported by the Fundamental Research Grant Scheme, Ministry of Higher Education, Malaysia (FRGS/1/2019/SKK06/USM/03/3).

Institutional Review Board Statement: Not applicable.

Informed Consent Statement: Not applicable.

Data Availability Statement: Not applicable.

Acknowledgments: We would like to thank School of Medical Sciences, Universiti Sains Malaysia for the research support.

Conflicts of Interest: The authors declare no conflict of interest.

\section{References}

1. Kamiya, K.; Kishimoto, M.; Sugai, J.; Komine, M.; Ohtsuki, M. Risk factors for the development of psoriasis. Int. J. Mol. Sci. 2019, 20, 4347. [CrossRef] [PubMed]

2. National Psoriasis Foundation. Get the Facts about Psoriasis and Psoriatic Arthritis. The National Psoriasis Foundation: National Psoriasis Foundation. 2017. Available online: https:/ / www.psoriasis.org/psoriasis-statistics (accessed on 28 November 2021).

3. Hayes, J.; Koo, J. Psoriasis: Depression, anxiety, smoking, and drinking habits. Dermatol. Ther. 2010, 23, 174-180. [CrossRef] [PubMed]

4. Springate, D.A.; Parisi, R.; Kontopantelis, E.; Reeves, D.; Griffiths, C.E.M.; Ashcroft, D.M. Incidence, prevalence and mortality of patients with psoriasis: A UK population-based cohort study. Adv. Exp. Med. 2017, 176, 650-658. [CrossRef] [PubMed]

5. Huang, T.-H.; Lin, C.-F.; Alalaiwe, A.; Yang, S.-C.; Fang, J.-Y. Apoptotic or antiproliferative activity of natural products against keratinocytes for the treatment of psoriasis. Int. J. Mol. Sci. 2019, 20, 2558. [CrossRef]

6. Kim, H.O.; Kang, S.Y.; Kim, J.C.; Park, C.W.; Chung, B.Y. Pediatric psoriasis: From new insights into pathogenesis to updates on treatment. Biomedicines 2021, 9, 940. [CrossRef]

7. Pithadia, D.J.; Reynolds, K.A.; Lee, E.B.; Wu, J.J. Psoriasis-associated cutaneous pain: Etiology, assessment, impact, and management. J. Dermatol. Treat. 2019, 30, 435-440. [CrossRef]

8. Rajguru, J.P.; Maya, D.; Kumar, D.; Suri, P.; Bhardwaj, S.; Patel, N.D. Update on psoriasis: A review. J. Fam. Med. Prim. Care Rev. 2020, 29, 20. [CrossRef]

9. Kimmel, G.W.; Lebwohl, M. Psoriasis: Overview and diagnosis. evidence-based psoriasis: Diagnosis and treatment. In Updates in Clinical Dermatology; Springer: Cham, Swirzerland, 2021; pp. 1-16. [CrossRef]

10. Heidenreich, R.; Röcken, M.; Ghoreschi, K. Angiogenesis drives psoriasis pathogenesis. Int. J. Clin. Exp. Pathol. 2009, 90, 232-248. [CrossRef]

11. Talaee, R.; Hajheydari, Z;; Moghaddam, A.Y.; Seyyed Alireza Moraveji, S.A.; Ravandi, B.F. Prevalence of oral mucosal lesions and their association with severity of psoriasis among psoriatic patients referred to dermatology clinic: A cross-sectional study in Kashan/Iran. Open Access Maced. J. Med. Sci. 2017, 5, 978-982. [CrossRef]

12. Leon, A.; Liao, W.J.; Gupta, R.; Koo, J.Y.; Wu, J.J. Tumor necrosis factor- $\alpha$ triad: Psoriasis, cardiovascular disease, and depression. Psoriasis Forum 2013, 19, 41-49. [CrossRef]

13. Mattei, P.L.; Corey, K.C.; Kimball, A.B. Psoriasis Area Severity Index (PASI) and the Dermatology Life Quality Index (DLQI): The correlation between disease severity and psychological burden in patients treated with biological therapies. J. Eur. Acad. Dermatol. Venereol. 2014, 28, 333-337. [CrossRef] [PubMed] 
14. Otero, M.E.; Van Geel, M.J.; Hendriks, J.C.M.; van de Kerkhof, P.C.M.; Seyger, M.M.B.; de Jong, E.M.G.J. A pilot study on the Psoriasis Area and Severity Index (PASI) for small areas: Presentation and implications of the Low PASI score. J. Dermatol. Treat. 2015, 26, 314-317. [CrossRef] [PubMed]

15. Grjibovski, A.M.; Olsen, A.O.; Magnus, P.; Harris, J.R. Psoriasis in Norwegian twins: Contribution of genetic and environmental effects. J. Eur. Acad. Dermatol. 2007, 21, 1337-1343. [CrossRef] [PubMed]

16. Gupta, R.; Debbaneh, M.G.; Liao, W. Genetic epidemiology of psoriasis. Curr. Dermatol. Rep. 2014, 3, 61-78. [CrossRef]

17. Coimbra, S.; Oliveira, H.; Reis, F.; Belo, L.; Rocha, S.; Quintanilha, A.; Figueiredo, A.; Teixeira, F.; Castro, E.; Rocha-Pereira, P.; et al. Interleukin (IL)-22, IL-17, IL-23, IL-8, vascular endothelial growth factor and tumour necrosis factor- $\alpha$ levels in patients with psoriasis before, during and after psoralen-ultraviolet A and narrowband ultraviolet B therapy. Br. J. Dermatol. Suppl. 2010, 163, 1282-1290. [CrossRef]

18. Baliwag, J.; Barnes, D.H.; Johnston, A. Cytokines in psoriasis. Cytokine 2015, 73, 342-350. [CrossRef]

19. Oliveira, M.D.F.S.P.D.; Rocha, B.D.O.; Duarte, G.V. Psoriasis: Classical and emerging comorbidities. An. Bras. Dermatol. 2015, 90, 9-20. [CrossRef]

20. Woo, Y.R.; Park, C.J.; Kang, H.; Kim, J.E. The risk of systemic diseases in those with psoriasis and psoriatic arthritis: From mechanisms to clinic. Int. J. Mol. Sci. 2020, 21, 7041. [CrossRef]

21. Albanesi, C.; Madonna, S.; Gisondi, P.; Girolomoni, G. The interplay between keratinocytes and immune cells in the pathogenesis of psoriasis. Front. Immunol. 2018, 9, 1549. [CrossRef]

22. Takahashi, T.; Yamasaki, K. Psoriasis and antimicrobial peptides. Int. J. Mol. Sci. 2020, 21, 6791. [CrossRef]

23. Dhar, S.; Banerjee, R.; Agrawal, N.; Chatterjee, S.; Malakar, R. Psoriasis in children: An insight. Indian J. Dermatol. 2011, 56, 262. [CrossRef] [PubMed]

24. Rakhshan, A.; Zarrinpour, N.; Moradi, A.; Ahadi, M.; Omrani, M.D.; Ghafouri-Fard, S.; Taheri, M. Genetic variants within ANRIL (antisense non coding RNA in the INK4 locus) are associated with risk of psoriasis. Int. Immunopharmacol. 2020, 78, 106053. [CrossRef] [PubMed]

25. Kara Polat, A.; Oguz Topal, I.; Karadag, A.S.; Aksoy, H.; Koku Aksu, A.E.; Ozkur, E.; Akbulut, T.O.; Demir, F.T.; Engin, B.; Uzuncakmak, T.K.; et al. The impact of COVID-19 in patients with psoriasis: A multicenter study in Istanbul. Dermatol. Ther. 2021, 34, e14691. [CrossRef] [PubMed]

26. Campanati, A.; Marani, A.; Martina, E.; Diotallevi, F.; Radi, G.; Offidani, A. Psoriasis as an immune-mediated and inflammatory systemic disease: From pathophysiology to novel therapeutic approaches. Biomedicines 2021, 9, 1511. [CrossRef]

27. Lew, W.; Bowcock, A.M.; Krueger, J.G. Psoriasis vulgaris: Cutaneous lymphoid tissue supports T-cell activation and 'Type 1'inflammatory gene expression. Trends Immunol. 2004, 25, 295-305. [CrossRef]

28. Schon, M.; Behmenburg, C.; Denzer, D.; Schon, M.P. Pathogenic function of IL-1beta in psoriasiform skin lesions of flaky skin (fsn/fsn) mice. Clin. Exp. Immunol. 2001, 123, 505-510. [CrossRef]

29. Zhu, J.; Paul, W.E. Heterogeneity and plasticity of T helper cells. Cell Res. 2010, 20, 4-12. [CrossRef]

30. Chiricozzi, A.; Guttman-Yassky, E.; Suárez-Farinas, M.; Nograles, K.E.; Tian, S.; Cardinale, I.; Chimenti, S.; Krueger, J.G. Integrative responses to IL-17 and TNF- $\alpha$ in human keratinocytes account for key inflammatory pathogenic circuits in psoriasis. J. Investig. Dermatol. 2011, 131, 677-687. [CrossRef]

31. Saeki, H.; Imafuku, S.; Abe, M.; Shintani, Y.; Onozuka, D.; Hagihara, A.; Katoh, N.; Murota, H.; Takeuchi, S.; Sugaya, M.; et al. Poor adherence to medication as assessed by the Morisky Medication Adherence Scale- 8 and low satisfaction with treatment in 237 psoriasis patients. J. Dermatol. 2015, 42, 367-372. [CrossRef]

32. Nast, A.; Jacobs, A.; Rosumeck, S.; Werner, R.N. Efficacy and safety of systemic long-term treatments for moderate-to-severe psoriasis: A systematic review and meta-analysis. J. Investig. Dermatol. 2015, 135, 2641-2648. [CrossRef]

33. Kaushik, S.B.; Lebwohl, M.G. Review of safety and efficacy of approved systemic psoriasis therapies. Int. J. Dermatol. 2019, 58, 649-658. [CrossRef] [PubMed]

34. Torres, T.; Filipe, P. Small molecules in the treatment of psoriasis. Drug Dev. Res. 2015, 76, 215-227. [CrossRef] [PubMed]

35. Gisondi, P.; Del Giglio, M.; Girolomoni, G. Treatment approaches to moderate to severe psoriasis. Int. J. Mol. Sci. 2017, 18, 2427. [CrossRef] [PubMed]

36. Rønholt, K.; Iversen, L. Old and new biological therapies for psoriasis. Int. J. Mol. Sci. 2017, 18, 2297. [CrossRef]

37. Ortonne, J.P.; Prinz, J.C. Alefacept: A novel and selective biologic agent for the treatment of chronic plaque psoriasis. Eur. J. Dermatol. 2004, 14, 41-45.

38. Liu, C.M.; McKenna, J.K.; Krueger, G.G. Alefacept: A novel biologic in the treatment of psoriasis. Drugs Today 2004, 40, 961-974. [CrossRef]

39. Langley, R.G.; Cherman, A.M.; Gupta, A.K. Alefacept: An expert review concerning the treatment of psoriasis. Expert Opin. Pharmacother. 2005, 6, 2327-2333. [CrossRef]

40. Jenneck, C.; Novak, N. The safety and efficacy of alefacept in the treatment of chronic plaque psoriasis. Ther. Clin. Risk Manag. 2007, 3, 411-420.

41. Lebwohl, M. Psoriasis. Lancet 2003, 361, 1197-1204. [CrossRef]

42. Sivamani, R.K.; Correa, G.; Ono, Y.; Bowen, M.P.; Raychaudhuri, S.P.; Maverakis, E. Biological therapy of psoriasis. Indian J. Dermatol. 2010, 55, 161. [CrossRef] 
43. Bak, R.O.; Mikkelsen, J.G. Regulation of cytokines by small RNAs during skin inflammation. J. Biomed. Sci. 2010, 17, 53. [CrossRef] [PubMed]

44. Wang, Z.; Zheng, H.; Zhou, H.; Huang, N.; Wei, X.; Liu, X.; Teng, X.; Hu, Z.; Zhang, J.; Zhou, X.; et al. Systematic screening and identification of novel psoriasis-specific genes from the transcriptome of psoriasis-like keratinocytes. Mol. Med. Rep. 2019, 19, 1529-1542. [CrossRef] [PubMed]

45. Gottlieb, A.B.; Chamian, F.; Masud, S.; Cardinale, I.; Abello, M.V.; Lowes, M.A.; Chen, F.; Magliocco, M.; Krueger, J.G. TNF inhibition rapidly down-regulates multiple proinflammatory pathways in psoriasis plaques. J. Immunol. 2005, 175, 2721-2729. [CrossRef] [PubMed]

46. Grine, L.; Dejager, L.; Libert, C.; Vandenbroucke, R.E. An inflammatory triangle in psoriasis: TNF, type I IFNs and IL-17. Cytokine Growth Factor Rev. 2015, 26, 25-33. [CrossRef] [PubMed]

47. Mylonas, A.; Conrad, C. Psoriasis: Classical vs. paradoxical. the yin-yang of TNF and Type I interferon. Front. Immunol. 2018, 9, 2746. [CrossRef] [PubMed]

48. Calzascia, T.; Pellegrini, M.; Hall, H.; Sabbagh, L.; Ono, N.; Elford, A.R.; Ohashi, P.S. TNF- $\alpha$ is critical for antitumor but not antiviral T cell immunity in mice. J. Clin. Investig. 2007, 117, 3833-3845. [CrossRef] [PubMed]

49. Chen, X.; Hamano, R.; Subleski, J.J.; Hurwitz, A.A.; Howard, O.Z.; Oppenheim, J.J. Expression of costimulatory TNFR2 induces resistance of $\mathrm{CD}^{+}{ }^{+}$FoxP3 - conventional T cells to suppression by $\mathrm{CD}^{+}{ }^{+} \mathrm{FoxP}^{+}$regulatory T cells. J. Immunol. 2010, 185, 174-182 [CrossRef]

50. Prieto-Perez, R.; Cabaleiro, T.; Dauden, E.; Abad-Santos, F. Gene polymorphisms that can predict response to anti-TNF therapy in patients with psoriasis and related autoimmune diseases. Pharm. J. 2013, 13, 297-305. [CrossRef]

51. Zhuang, L.; Ma, W.; Cai, D.; Zhong, H.; Sun, Q. Associations between tumor necrosis factor-a polymorphisms and risk of psoriasis: A meta-analysis. PLoS ONE 2013, 8, e68827. [CrossRef]

52. Murdaca, G.; Gulli, R.; Spano, F.; Lantieri, F.; Burlando, M.; Parodi, A.; Mandich, P.; Puppo, F. TNF- $\alpha$ gene polymorphisms: Association with disease susceptibility and response to anti-TNF- $\alpha$ treatment in psoriatic arthritis. J. Investig. Dermatol. 2014, 134, 2503-2509. [CrossRef]

53. Mazloom, S.E.; Yan, D.; Hu, J.Z.; Ya, J.; Husni, M.E.; Warren, C.B.; Fernandez, A.P. TNF- $\alpha$ inhibitor-induced psoriasis: A decade of experience at the Cleveland Clinic. JAAD 2020, 83, 1590-1598. [CrossRef] [PubMed]

54. Ruano, J.; Suárez-Fariñas, M.; Shemer, A.; Oliva, M.; Guttman-Yassky, E.; Krueger, J.G. Molecular and cellular profiling of scalp psoriasis reveals differences and similarities compared to skin psoriasis. PLoS ONE 2016, 11, e0148450. [CrossRef] [PubMed]

55. Tsoi, L.C.; Spain, S.L.; Ellinghaus, E.; Stuart, P.E.; Capon, F.; Knight, J.; Tejasvi, T.; Kang, H.M.; Allen, M.H.; Lambert, S.; et al. Enhanced meta-analysis and replication studies identify five new psoriasis susceptibility loci. Nat. Commun. 2015, 6, 7001. [CrossRef] [PubMed]

56. Johnston, A.; Fritz, Y.; Dawes, S.M.; Diaconu, D.; Al-Attar, P.M.; Guzman, A.M.; Chen, C.S.; Fu, W.; Gudjonsson, J.E.; McCormick T.S.; et al. Keratinocyte overexpression of IL-17C promotes psoriasiform skin inflammation. J. Immunol. 2013, 190, $2252-2262$. [CrossRef] [PubMed]

57. Banno, T.; Gazel, A.; Blumenberg, M. Effects of tumor necrosis factor- $\alpha$ (TNF $\alpha)$ in epidermal keratinocytes revealed using global transcriptional profiling. J. Biol. Chem. 2004, 279, 32633-32642. [CrossRef] [PubMed]

58. Yost, J.; Gudjonsson, J.E. The role of TNF inhibitors in psoriasis therapy: New implications for associated comorbidities. Med. Rep. 2009, 1, 30. [CrossRef] [PubMed]

59. Brownstone, N.D.; Hong, J.; Mosca, M.; Hadeler, E.; Liao, W.; Bhutani, T.; Koo, J. Biologic treatments of psoriasis: An update for the clinician. Biol. Targets Ther. 2019, 15, 39. [CrossRef]

60. Nguyen, T.U.; Koo, J. Etanercept in the treatment of plaque psoriasis. Clinical, cosmetic and investigational dermatology. Clin. Cosmet. Investig. 2009, 19, 77-84. [CrossRef]

61. Sedger, L.M.; McDermott, M.F. TNF and TNF-receptors: From mediators of cell death and inflammation to therapeutic giants-past, present and future. Cytokine Growth Factor Rev. 2014, 25, 453-472. [CrossRef]

62. Kivelevitch, D.; Mansouri, B.; Menter, A. Long term efficacy and safety of etanercept in the treatment of psoriasis and psoriatic arthritis. Biol. Targets Ther. 2014, 8, 169. [CrossRef]

63. Knight, D.M.; Trinh, H.; Le, J.; Siegel, S.; Shealy, D.; McDonough, M.; Ghrayeb, J. Construction and initial characterization of a mouse-human chimeric anti-TNF antibody. Mol. Immunol. 1993, 30, 1443-1453. [CrossRef]

64. Kaymakcalan, Z.; Sakorafas, P.; Bose, S.; Scesney, S.; Xiong, L.; Hanzatian, D.K.; Salfeld, J.; Sasso, E.H. Comparisons of affinities, avidities, and complement activation of adalimumab, infliximab, and etanercept in binding to soluble and membrane tumor necrosis factor. Clin. Immunol. 2009, 131, 308-316. [CrossRef] [PubMed]

65. Talbot, C.; Sagar, P.M.; Johnston, M.J.; Finan, P.J.; Burke, D. Infliximab in the surgical management of complex fistulating anal Crohn's disease. Int. J. Colorectal Dis. 2005, 7, 164-168. [CrossRef] [PubMed]

66. Tracey, D.; Klareskog, L.; Sasso, E.H.; Salfeld, J.G.; Tak, P.P. Tumor necrosis factor antagonist mechanisms of action: A comprehensive review. Pharmacol. Ther. 2008, 117, 244-279. [CrossRef] [PubMed]

67. Antoni, C.; Krueger, G.G.; de Vlam, K.; Birbara, C.; Beutler, A.; Guzzo, C.; Zhou, B.; Dooley, L.T.; Kavanaugh, A. Infliximab improves signs and symptoms of psoriatic arthritis: Results of the IMPACT 2 trial. Ann. Rheum. Dis. 2005, 64, 1150-1157. [CrossRef] [PubMed] 
68. Subedi, S.; Gong, Y.; Chen, Y.; Shi, Y. Infliximab and biosimilar infliximab in psoriasis: Efficacy, loss of efficacy, and adverse events. Drug Des. Devel. Ther. 2019, 13, 2491-2502. [CrossRef] [PubMed]

69. Mazza, J.; Rossi, A.; Weinberg, J.M. Innovative uses of tumor necrosis factor $\alpha$ inhibitors. Dermatol. Clin. 2010, 28, 559-575. [CrossRef]

70. Chiricozzi, A.; Zangrilli, A.; Bavetta, M.; Bianchi, L.; Chimenti, S.; Saraceno, R. Real-life 9-year experience with adalimumab in psoriasis and psoriatic arthritis: Results of a single-centre, retrospective study. J. Eur. Acad. Dermatol. 2017, 31, 304-311. [CrossRef]

71. Kamata, M.; Tada, Y. Efficacy and safety of biologics for psoriasis and psoriatic arthritis and their impact on comorbidities: A literature review. Int. J. Mol. Sci. 2020, 21, 1690. [CrossRef]

72. Xu, Z.; Vu, T.; Lee, H.; Hu, C.; Ling, J.; Yan, H.; Baker, D.; Beutler, A.; Pendley, C.; Wagner, C.; et al. Population pharmacokinetics of golimumab, an anti-tumor necrosis factor- $\alpha$ human monoclonal antibody, in patients with psoriatic arthritis. J. Clin. Pharmacol. 2009, 49, 1056-1070. [CrossRef]

73. Shealy, D.J.; Cai, A.; Staquet, K.; Baker, A.; Lacy, E.R.; Johns, L.; Vafa, O.; Gunn, G.; Tam, S.; Sague, S.; et al. Characterization of golimumab, a human monoclonal antibody specific for human tumor necrosis factor $\alpha$. MAbs Taylor Fr. 2010, 2, 428-439. [CrossRef] [PubMed]

74. Reich, K.; Burden, A.D.; Eaton, J.N.; Hawkins, N.S. Efficacy of biologics in the treatment of moderate to severe psoriasis: A network meta-analysis of randomized controlled trials. Br. J. Dermatol. 2012, 166, 179-188. [CrossRef] [PubMed]

75. Mariette, X.; Förger, F.; Abraham, B.; Flynn, A.D.; Moltó, A.; Flipo, R.M.; van Tubergen, A.; Shaughnessy, L.; Simpson, J.; Teil, M.; et al. Lack of placental transfer of certolizumab pegol during pregnancy: Results from CRIB, a prospective, postmarketing, pharmacokinetic study. ARD 2018, 77, 228-233. [CrossRef]

76. Nesbitt, A.; Fossati, G.; Bergin, M.; Stephens, P.; Stephens, S.; Foulkes, R.; Brown, D.; Robinson, M.; Bourne, T. Mechanism of action of certolizumab pegol (CDP870): In vitro comparison with other anti-tumor necrosis factor $\alpha$ agents. Inflamm. Bowel Dis. 2007, 13, 1323-1332. [CrossRef] [PubMed]

77. Garcia, V.R.; Burls, A.; Cabello, J.B.; Casasempere, P.V.; Bort-Marti, S.; Bernal, J.A. Certolizumab pegol (CDP870) for rheumatoid arthritis in adults. Cochrane Database Syst. Rev. 2017, 9, CD007649. [CrossRef]

78. Esposito, M.; Carubbi, F.; Giunta, A.; Alunno, A.; Giacomelli, R.; Fargnoli, M.C. Certolizumab pegol for the treatment of psoriatic arthritis and plaque psoriasis. Expert Rev. Clin. Immunol. 2020, 16, 119-128. [CrossRef] [PubMed]

79. $\quad$ Langley, R.G.; Elewski, B.E.; Lebwohl, M.; Reich, K.; Griffiths, C.E.M.; Papp, K.; Puig, L.; Nakagawa, H.; Spelman, L.; Sigurgeirsson, B.; et al. Secukinumab in plaque psoriasis-Results of two phase 3 trials. NEJM 2014, 371, 326-338. [CrossRef]

80. Malakouti, M.; Brown, G.E.; Wang, E.; Koo, J.; Levin, E.C. The role of IL-17 in psoriasis. J. Dermatol. Treat. 2015, 26, 41-44. [CrossRef]

81. Li, H.; Chen, J.; Huang, A.; Stinson, J.; Heldens, S.; Foster, J.; Dowd, P.; Gurney, A.L.; Wood, W.I. Cloning and characterization of IL-17B and IL-17C, two new members of the IL-17 cytokine family. Proc. Natl. Acad. Sci. USA 2000, 97, 773-778. [CrossRef]

82. Fort, M.M.; Cheung, J.; Yen, D.; Li, J.; Zurawski, S.M.; Lo, S.; Menon, S.; Clifford, T.; Hunte, B.; Lesley, R.; et al. IL-25 induces IL-4, IL-5, and IL-13 and Th2-associated pathologies in vivo. Immunity 2001, 15, 985-995. [CrossRef]

83. Hymowitz, S.G.; Filvaroff, E.H.; Yin, J.; Lee, J.; Cai, L.; Risser, P.; Maruoka, M.; Mao, W.; Foster, J.; Kelley, R.F.; et al. IL-17s adopt a cystine knot fold: Structure and activity of a novel cytokine, IL-17F, and implications for receptor binding. EMBO J. 2001, 20, 5332-5341. [CrossRef] [PubMed]

84. Gaffen, S.L. Recent advances in the IL-17 cytokine family. Curr. Opin. 2011, 23, 613-619. [CrossRef] [PubMed]

85. Frieder, J.; Kivelevitch, D.; Menter, A. Secukinumab: A review of the anti-IL-17A biologic for the treatment of psoriasis. TACD 2018, 9, 5-21. [CrossRef] [PubMed]

86. Wang, M.; Zhang, S.; Zheng, G.; Huang, J.; Songyang, Z.; Zhao, X.; Lin, X. Gain-of-function mutation of CARD14 leads to spontaneous psoriasis-like skin inflammation through enhanced keratinocyte response to IL-17A. Immunity 2018, 49, 66-79. [CrossRef]

87. Erbel, C.; Akhavanpoor, M.; Okuyucu, D.; Wangler, S.; Dietz, A.; Zhao, L.; Stellos, K.; Little, K.M.; Lasitschka, F.; Doesch, A.; et al. IL-17A influences essential functions of the monocyte/macrophage lineage and is involved in advanced murine and human atherosclerosis. J. Immunol. 2014, 193, 4344-4355. [CrossRef]

88. Von Stebut, E.; Boehncke, W.H.; Ghoreschi, K.; Gori, T.; Kaya, Z.; Thaci, D.; Schäffler, A. IL-17A in psoriasis and beyond: Cardiovascular and metabolic implications. Front. Immunol. 2020, 10, 3096. [CrossRef]

89. Martin, D.A.; Towne, J.E.; Kricorian, G.; Klekotka, P.; Gudjonsson, J.E.; Krueger, J.G.; Russell, C.B. The emerging role of IL-17 in the pathogenesis of psoriasis: Preclinical and clinical findings. J. Investig. Dermatol. 2013, 133, 17-26. [CrossRef]

90. Gordon, K.B.; Blauvelt, A.; Papp, K.A.; Langley, R.G.; Luger, T.; Ohtsuki, M.; Reich, K.; Amato, D.; Ball, S.G.; Braun, D.K.; et al. Phase 3 trials of ixekizumab in moderate-to-severe plaque psoriasis. NEJM 2016, 375, 345-356. [CrossRef]

91. Huang, X.D.; Zhang, H.; He, M.X. Comparative and evolutionary analysis of the interleukin 17 gene family in invertebrates. PLoS ONE 2015, 10, e0132802. [CrossRef]

92. Angkasekwinai, P.; Park, H.; Wang, Y.H.; Wang, Y.H.; Chang, S.H.; Corry, D.B.; Liu, Y.J.; Zhu, Z.; Dong, C. Interleukin 25 promotes the initiation of proallergic type 2 responses. Exp. Med. 2007, 204, 1509-1517. [CrossRef]

93. Wasilewska, A.; Winiarska, M.; Olszewska, M.; Rudnicka, L. Interleukin-17 inhibitors. A new era in treatment of psoriasis and other skin diseases. Postepy Dermatol Alergol. 2016, 33, 247. [CrossRef] [PubMed] 
94. Krueger, J.G.; Fretzin, S.; Suárez-Fariñas, M.; Haslett, P.A.; Phipps, K.M.; Cameron, G.S.; McColm, J.; Katcherian, A.; Cueto, I.; White, T.; et al. IL-17A is essential for cell activation and inflammatory gene circuits in subjects with psoriasis. J. Allergy Clin. Immunol. 2012, 130, 145-154. [CrossRef] [PubMed]

95. Kirkham, B.W.; Kavanaugh, A.; Reich, K. Interleukin-17A: A unique pathway in immune-mediated diseases: Psoriasis, psoriatic arthritis and rheumatoid arthritis. Immunology 2014, 141, 133-142. [CrossRef] [PubMed]

96. Hijnen, D.; Knol, E.F.; Gent, Y.Y.; Giovannone, B.; Beijn, S.J.; Kupper, T.S.; Bruijnzeel-Koomen, C.A.F.M.; Clark, R.A. CD8 ${ }^{+}$T cells in the lesional skin of atopic dermatitis and psoriasis patients are an important source of IFN- $\gamma$, IL-13, IL-17, and IL-22. J. Investig. Dermatol. 2013, 133, 973-979. [CrossRef]

97. Slominski, A.T.; Hardeland, R.; Zmijewski, M.A.; Slominski, R.M.; Reiter, R.J.; Paus, R. Melatonin: A cutaneous perspective on its production, metabolism, and functions. J. Investig. Dermatol. 2018, 138, 490-499. [CrossRef]

98. Starnes, T.; Broxmeyer, H.E.; Robertson, M.J.; Hromas, R. Cutting edge: IL-17D, a novel member of the IL-17 family, stimulates cytokine production and inhibits hemopoiesis. J. Immunol. 2002, 2169, 642-646. [CrossRef]

99. Miossec, P.; Kolls, J.K. Targeting IL-17 and Th 17 cells in chronic inflammation. Nat. Rev. Drug Discov. 2012, 11, 763-776. [CrossRef]

100. Ruddy, M.J.; Wong, G.C.; Liu, X.K.; Yamamoto, H.; Kasayama, S.; Kirkwood, K.L.; Gaffen, S.L. Functional cooperation between interleukin-17 and tumor necrosis factor- $\alpha$ is mediated by CCAAT/enhancer-binding protein family members. J. Biol. Chem. 2004, 279, 2559-2567. [CrossRef]

101. Laan, M.; Cui, Z.H.; Hoshino, H.; Lötvall, J.; Sjöstrand, M.; Gruenert, D.C.; Skoogh, B.E.; Lindén, A. Neutrophil recruitment by human IL-17 via CXC chemokine release in the airways. J. Immunol. 1999, 162, 2347-2352.

102. Moseley, T.A.; Haudenschild, D.R.; Rose, L.; Reddi, A.H. Interleukin-17 family and IL-17 receptors. Cytokine Growth Factor Rev. 2003, 14, 155-174. [CrossRef]

103. Harper, E.G.; Guo, C.; Rizzo, H.; Lillis, J.V.; Kurtz, S.E.; Skorcheva, I.; Purdy, D.; Fitch, E.; Iordanov, M.; Blauvelt, A. Th17 cytokines stimulate CCL20 expression in keratinocytes in vitro and in vivo: Implications for psoriasis pathogenesis. J. Investig. Dermatol. 2009, 129, 2175-2183. [CrossRef] [PubMed]

104. Johansen, C.; Usher, P.A.; Kjellerup, R.B.; Lundsgaard, D.; Iversen, L.; Kragballe, K. Characterization of the interleukin-17 isoforms and receptors in lesional psoriatic skin. Br. J. Dermatol. Suppl. 2009, 160, 319-324. [CrossRef] [PubMed]

105. Yilmaz, S.B.; Cicek, N.; Coskun, M.; Yegin, O.; Alpsoy, E. Serum and tissue levels of IL-17 in different clinical subtypes of psoriasis. Arch. Dermatol. 2012, 304, 465-469. [CrossRef] [PubMed]

106. Gaffen, S.L. Structure and signalling in the IL-17 receptor family. Nat. Rev. Immunol. 2009, 9, 556-567. [CrossRef]

107. Fujishima, S.; Watanabe, H.; Kawaguchi, M.; Suzuki, T.; Matsukura, S.; Homma, T.; Howell, B.G.; Hizawa, N.; Mitsuya, T.; Huang, S.K.; et al. Involvement of IL-17F via the induction of IL-6 in psoriasis. Arch. Dermatol. 2010, 302, 499-505. [CrossRef]

108. Pantelyushin, S.; Haak, S.; Ingold, B.; Kulig, P.; Heppner, F.L.; Navarini, A.A.; Becher, B. Ror $\gamma t+$ innate lymphocytes and $\gamma \delta \mathrm{T}$ cells initiate psoriasiform plaque formation in mice. J. Clin. Investig. 2012, 122, 2252-2256. [CrossRef]

109. Soderstrom, C.; Berstein, G.; Zhang, W.; Valdez, H.; Fitz, L.; Kuhn, M.; Fraser, S. Ultra-sensitive measurement of IL-17A and IL-17F in psoriasis patient serum and skin. AAPS J. 2017, 19, 1218-1222. [CrossRef]

110. Ramirez-Carrozzi, V.; Sambandam, A.; Luis, E.; Lin, Z.; Jeet, S.; Lesch, J.; Hackney, J.; Kim, J.; Zhou, M.; Lai, J.; et al. IL-17C regulates the innate immune function of epithelial cells in an autocrine manner. Nat. Immunol. 2011, 12, 1159-1166. [CrossRef]

111. Chang, S.H.; Reynolds, J.M.; Pappu, B.P.; Chen, G.; Martinez, G.J.; Dong, C. Interleukin-17C promotes Th17 cell responses and autoimmune disease via interleukin-17 receptor E. Immunity 2011, 35, 611-621. [CrossRef]

112. Song, X.; Zhu, S.; Shi, P.; Liu, Y.; Shi, Y.; Levin, S.D.; Qian, Y. IL-17RE is the functional receptor for IL-17C and mediates mucosal immunity to infection with intestinal pathogens. Nat. Immunol. 2011, 12, 1151-1158. [CrossRef]

113. Song, X.; Gao, H.; Qian, Y. Th17 differentiation and their pro-inflammation function. Adv. Exp. Med. 2014, 841, 99-151. [CrossRef]

114. Reszke, R.; Szepietowski, J.C. Secukinumab in the treatment of psoriasis: An update. Immunotherapy 2017, 9, 229-238. [CrossRef] [PubMed]

115. Deodhar, A.; Mease, P.J.; McInnes, I.B.; Baraliakos, X.; Reich, K.; Blauvelt, A.; Leonardi, C.; Porter, B.; Gupta, A.D.; Widmer, A.; et al. Long-term safety of secukinumab in patients with moderate-to-severe plaque psoriasis, psoriatic arthritis, and ankylosing spondylitis: Integrated pooled clinical trial and post-marketing surveillance data. Arthritis Res. Ther. 2019, 21, 111. [CrossRef] [PubMed]

116. Yang, E.J.; Beck, K.M.; Liao, W. Secukinumab in the treatment of psoriasis: Patient selection and perspectives. Psoriasis (Auckl.) 2018, 8, 75. [CrossRef] [PubMed]

117. Kolbinger, F.; Loesche, C.; Valentin, M.A.; Jiang, X.; Cheng, Y.; Jarvis, P.; Peters, T.; Calonder, C.; Bruin, G.; Polus, F.; et al. $\beta$-Defensin 2 is a responsive biomarker of IL-17A-driven skin pathology in patients with psoriasis. J. Allergy Clin. Immunol. 2017, 139, 923-932. [CrossRef]

118. Toussirot, E. Ixekizumab: An anti-IL-17A monoclonal antibody for the treatment of psoriatic arthritis. Expert Opin. Biol. Ther. 2018, 18, 101-107. [CrossRef]

119. Blegvad, C.; Skov, L.; Zachariae, C. Ixekizumab for the treatment of psoriasis: An update on new data since first approval. Expert Rev. Clin. Immunol. 2019, 15, 111-121. [CrossRef]

120. Zaba, L.C.; Suárez-Fariñas, M.; Fuentes-Duculan, J.; Nograles, K.E.; Guttman-Yassky, E.; Cardinale, I.; Lowes, M.A.; Krueger, J.G. Effective treatment of psoriasis with etanercept is linked to suppression of IL-17 signaling, not immediate response TNF genes. J. Allergy Clin. Immunol. 2009, 124, 1022-1030. [CrossRef] 
121. Blauvelt, A.; Reich, K.; Tsai, T.F.; Tyring, S.; Vanaclocha, F.; Kingo, K.; Ziv, M.; Pinter, A.; Vender, R.; Hugot, S.; et al. Secukinumab is superior to ustekinumab in clearing skin of subjects with moderate-to-severe plaque psoriasis up to 1 year: Results from the CLEAR study. JAAD 2017, 76, 60-69. [CrossRef]

122. Puig, L. Brodalumab: The first anti-IL-17 receptor agent for psoriasis. Drugs Today 2017, 53, 283-297. [CrossRef]

123. Foulkes, A.C.; Warren, R.B. Brodalumab in psoriasis: Evidence to date and clinical potential. Drugs Context 2019, 8, 212570. [CrossRef] [PubMed]

124. Russell, C.B.; Rand, H.; Bigler, J.; Kerkof, K.; Timour, M.; Bautista, E.; Krueger, J.G.; Salinger, D.H.; Welcher, A.A.; Martin, D.A Gene expression profiles normalized in psoriatic skin by treatment with brodalumab, a human anti-IL-17 receptor monoclonal antibody. J. Immunol. 2014, 192, 3828-3836. [CrossRef] [PubMed]

125. Nirula, A.; Nilsen, J.; Klekotka, P.; Kricorian, G.; Erondu, N.; Towne, J.E.; Russell, C.B.; Martin, D.A.; Budelsky, A.L. Effect of IL-17 receptor A blockade with brodalumab in inflammatory diseases. Rheumatology 2016, 55, 43-55. [CrossRef] [PubMed]

126. Ridker, P.M.; Everett, B.M.; Thuren, T.; MacFadyen, J.G.; Chang, W.H.; Ballantyne, C.; Fonseca, F.; Nicolau, J.; Koenig, W.; Anker, S.D.; et al. Antiinflammatory therapy with canakinumab for atherosclerotic disease. NEJM 2017, 377, 1119-1131. [CrossRef]

127. Chiricozzi, A.; Saraceno, R.; Chimenti, M.S.; Guttman-Yassky, E.; Krueger, J.G. Role of IL-23 in the pathogenesis of psoriasis: A novel potential therapeutic target? Expert Opin. Ther. Targets 2014, 18, 513-525. [CrossRef]

128. Chan, T.C.; Hawkes, J.E.; Krueger, J.G. Interleukin 23 in the skin: Role in psoriasis pathogenesis and selective interleukin 23 blockade as treatment. Ther. Adv. Chronic Dis. 2018, 9, 111-119. [CrossRef]

129. Chan, J.R.; Blumenschein, W.; Murphy, E.; Diveu, C.; Wiekowski, M.; Abbondanzo, S.; Bowman, E.P. IL-23 stimulates epidermal hyperplasia via TNF and IL-20R2-dependent mechanisms with implications for psoriasis pathogenesis. Exp. Med. 2006, 203, 2577-2587. [CrossRef]

130. Chen, L.; Deshpande, M.; Grisotto, M.; Smaldini, P.; Garcia, R.; He, Z.; Gulko, P.S.; Lira, S.A.; Furtado, G.C. Skin expression of IL-23 drives the development of psoriasis and psoriatic arthritis in mice. Sci. Rep. 2020, 10, 8259. [CrossRef]

131. Di Meglio, P.; Nestle, F.O. The role of IL-23 in the immunopathogenesis of psoriasis. F1000 Biol. 2010, 2, 40. [CrossRef]

132. Fotiadou, C.; Lazaridou, E.; Sotiriou, E.; Ioannides, D. Targeting IL-23 in psoriasis: Current perspectives. Psoriasis: Targets Ther. 2018, 8, 1-5. [CrossRef]

133. Papp, K.; Thaçi, D.; Reich, K.; Riedl, E.; Langley, R.G.; Krueger, J.G.; Gottlieb, A.B.; Nakagawa, H.; Bowman, E.P.; Mehta, A.; et al. Tildrakizumab (MK-3222), an anti-interleukin-23p19 monoclonal antibody, improves psoriasis in a phase IIb randomized placebo-controlled trial. Br. J. Dermatol. 2015, 173, 930-939. [CrossRef] [PubMed]

134. Banaszczyk, K. Tildrakizumab in the treatment of psoriasis-literature review. Reumatologia 2019, 57, 234. [CrossRef] [PubMed]

135. Reich, K.; Papp, K.A.; Blauvelt, A.; Tyring, S.K.; Sinclair, R.; Thaçi, D.; Nograles, K.; Mehta, A.; Cichanowitz, N.; Li, Q.; et al. Tildrakizumab versus placebo or etanercept for chronic plaque psoriasis (reSURFACE 1 and reSURFACE 2): Results from two randomised controlled, phase 3 trials. Lancet 2017, 390, 276-288. [CrossRef]

136. Gordon, K.B.; Duffin, K.C.; Bissonnette, R.; Prinz, J.C.; Wasfi, Y.; Li, S.; Shen, Y.K.; Szapary, P.; Randazzo, B.; Reich, K. A phase 2 trial of guselkumab versus adalimumab for plaque psoriasis. NEJM 2015, 373, 136-144. [CrossRef]

137. Sweet, K.; Song, Q.; Loza, M.J.; McInnes, I.B.; Ma, K.; Leander, K.; Franks, C.; Cooper, P.; Siebert, S. Guselkumab induces robust reduction in acute phase proteins and type 17 effector cytokines in active psoriatic arthritis: Results from phase 3 trials. $R M D$ Open 2021, 7, e001679. [CrossRef]

138. Jones, L.L.; Vignali, D.A. Molecular interactions within the IL-6/IL-12 cytokine/receptor superfamily. Immunol. Res. 2011, 51, 5-14. [CrossRef]

139. Lee, E.; Trepicchio, W.L.; Oestreicher, J.L.; Pittman, D.; Wang, F.; Chamian, F.; Dhodapkar, M.; Krueger, J.G. Increased expression of interleukin 23 p19 and p40 in lesional skin of patients with psoriasis vulgaris. J. Exp. Med. 2004, 199, 125-130. [CrossRef]

140. Jeon, C.; Sekhon, S.; Yan, D.; Afifi, L.; Nakamura, M.; Bhutani, T. Monoclonal antibodies inhibiting IL-12, -23 , and-17 for the treatment of psoriasis. Hum. Vaccines Immunother. 2017, 13, 2247-2259. [CrossRef]

141. Smeltz, R.B.; Chen, J.; Ehrhardt, R.; Shevach, E.M. Role of IFN- $\gamma$ in Th1 differentiation: IFN- $\gamma$ regulates IL-18R $\alpha$ expression by preventing the negative effects of IL-4 and by inducing/maintaining IL-12 receptor $\beta 2$ expression. J. Immunol. 2002, 168, 6165-6172. [CrossRef]

142. Wilson, N.J.; Boniface, K.; Chan, J.R.; McKenzie, B.S.; Blumenschein, W.M.; Mattson, J.D.; Basham, B.; Smith, K.; Chen, T.; Morel, F.; et al. Development, cytokine profile and function of human interleukin 17-producing helper T cells. Nat. Immunol. 2007, 8, 950-957. [CrossRef]

143. El-behi, M.; Ciric, B.; Yu, S.; Zhang, G.X.; Fitzgerald, D.C.; Rostami, A. Differential effect of IL-27 on developing versus committed Th17 cells. J. Immunol. 2009, 183, 4957-4967. [CrossRef] [PubMed]

144. Parham, C.; Chirica, M.; Timans, J.; Vaisberg, E.; Travis, M.; Cheung, J.; Pflanz, S.; Zhang, R.; Singh, K.P.; Vega, F.; et al. A receptor for the heterodimeric cytokine IL-23 is composed of IL-12R $\beta 1$ and a novel cytokine receptor subunit, IL-23R. J. Immunol. 2002, 168, 5699-5708. [CrossRef] [PubMed]

145. Zaghi, D.; Krueger, G.G. Ustekinumab: A review in the treatment of plaque psoriasis and psoriatic arthritis. J. Drugs Dermatol. 2012, 11, 160-167. [PubMed]

146. Brodmerkel, C.; Li, K.; Garcet, S.; Hayden, K.; Chiricozzi, A.; Novitskaya, I.; Krueger, J.G. Modulation of inflammatory gene transcripts in psoriasis vulgaris: Differences between ustekinumab and etanercept. J. Allergy Clin. Immunol. 2019, 143, 1965-1969. [CrossRef] 
147. Tohyama, M.; Yang, L.; Hanakawa, Y.; Dai, X.; Shirakata, Y. IFN- $\alpha$ enhances IL-22 receptor expression in keratinocytes: A possible role in the development of psoriasis. J. Investig. Dermatol. 2012, 2132, 1933-1937. [CrossRef]

148. Lande, R.; Gregorio, J.; Facchinetti, V.; Chatterjee, B.; Wang, Y.H.; Homey, B.; Cao, W.; Wang, Y.H.; Su, B.; Nestle, F.O.; et al Plasmacytoid dendritic cells sense self-DNA coupled with antimicrobial peptide. Nature 2007, 449, 564-569. [CrossRef]

149. Zhang, L.J.; Sen, G.L.; Ward, N.L.; Johnston, A.; Chun, K.; Chen, Y.; Adase, C.; Sanford, J.A.; Gao, N.; Chensee, M.; et al. Antimicrobial peptide LL37 and MAVS signaling drive interferon- $\beta$ production by epidermal keratinocytes during skin injury. Immunity 2016, 45, 119-130. [CrossRef]

150. Conrad, C.; Di Domizio, J.; Mylonas, A.; Belkhodja, C.; Demaria, O.; Navarini, A.A.; Lapointe, A.K.; French, L.E.; Vernez, M.V.; Gilliet, M. TNF blockade induces a dysregulated type I interferon response without autoimmunity in paradoxical psoriasis. Nat. Commun. 2018, 9, 25. [CrossRef]

151. Gui, J.; Gober, M.; Yang, X.; Katlinski, K.V.; Marshall, C.M.; Sharma, M.; Werth, V.P.; Baker, D.P.; Rui, H.; Seykora, J.T.; et al. Therapeutic elimination of the type 1 interferon receptor for treating psoriatic skin inflammation. J. Investig. Dermatol. 2016, 136, 1990-2002. [CrossRef]

152. Liu, Y.; Krueger, J.G.; Bowcock, A.M. Psoriasis: Genetic associations and immune system changes. Genes Immun. 2007, 8, 1-12. [CrossRef]

153. Shoeib, M.A.; El-Shafey, E.N.; Sonbol, A.A.; Lashin, S.E.R. Assessment of serum interferon- $\gamma$ in psoriasis. Menoufia Med. J. 2015, 28, 488. [CrossRef]

154. Kurtovic, N.O.; Halilovic, E.K. Serum concentrations of interferon gamma (IFN- $\gamma$ ) in patients with psoriasis: Correlation with clinical type and severity of the disease. Med. Arch. 2018, 72, 410. [CrossRef] [PubMed]

155. Yamamoto, M.; Imai, Y.; Sakaguchi, Y.; Haneda, T.; Yamanishi, K. Serum cytokines correlated with the disease severity of generalized pustular psoriasis. Dis. Markers 2013, 34, 153-161. [CrossRef] [PubMed]

156. Mehta, N.N.; Teague, H.L.; Swindell, W.R.; Baumer, Y.; Ward, N.L.; Xing, X.; Baugous, B.; Stuart, P.E.; Playford, M.; Voorhees, J.J.; et al. IFN- $\gamma$ and TNF- $\alpha$ synergism may provide a link between psoriasis and inflammatory atherogenesis. Sci. Rep. 2017, 7, 13831. [CrossRef] [PubMed]

157. Yano, S.; Banno, T.; Walsh, R.; Blumenberg, M. Transcriptional responses of human epidermal keratinocytes to cytokine interleukin-1. J. Cell. Physiol. 2008, 214, 1-13. [CrossRef]

158. Perera, G.K.; Di Meglio, P.; Nestle, F.O. Psoriasis. Annu. Rev. Pathol. 2012, 7, 385-422. [CrossRef]

159. Cai, Y.; Xue, F.; Quan, C.; Qu, M.; Liu, N.; Zhang, Y.; Fleming, C.; Hu, X.; Zhang, H.; Weichselbaum, R.; et al. A critical role of the IL-1 $\beta-I L-1 R$ signaling pathway in skin inflammation and psoriasis pathogenesis. J. Investig. Dermatol. 2019, 139, 146-156. [CrossRef]

160. Johnston, A.; Xing, X.; Guzman, A.M.; Riblett, M.; Loyd, C.M.; Ward, N.L.; Gudjonsson, J.E. IL-1F5, -F6, -F8, and-F9: A novel IL-1 family signaling system that is active in psoriasis and promotes keratinocyte antimicrobial peptide expression. J. Immunol. Res. 2011, 186, 2613-2622. [CrossRef]

161. Foster, A.M.; Baliwag, J.; Chen, C.S.; Guzman, A.M.; Stoll, S.W.; Gudjonsson, J.E.; Ward, N.L.; Johnston, A. IL-36 promotes myeloid cell infiltration, activation, and inflammatory activity in skin. J. Immunol. 2014, 192, 6053-6061. [CrossRef]

162. Mercurio, L.; Morelli, M.; Scarponi, C.; Eisenmesser, E.Z.; Doti, N.; Pagnanelli, G.; Gubinelli, E.; Mazzanti, C.; Cavani, A.; Ruvo, M.; et al. IL-38 has an anti-inflammatory action in psoriasis and its expression correlates with disease severity and therapeutic response to anti-IL-17A treatment. Cell Death Dis. 2018, 9, 1104. [CrossRef]

163. Saggini, A.; Chimenti, S.; Chiricozzi, A. IL-6 as a druggable target in psoriasis: Focus on pustular variants. J. Immunol. Res. 2014, 2014, 964069. [CrossRef] [PubMed]

164. Lise, M.L.Z.; Baptista, T.S.A.; Petersen, L.E.; Bauer, M.E.; Ungaretti, C.A.L.; Torres, E.; Harter, K.; Staub, H.L. Subclinical atherogenesis in patients with mild psoriasis: A role for IL-6? Rev. Assoc. Med. Bras. 2017, 63, 747-752. [CrossRef] [PubMed]

165. Duan, H.; Koga, T.; Kohda, F.; Hara, H.; Urabe, K.; Furue, M. Interleukin-8-positive neutrophils in psoriasis. J. Dermatol. Sci. 2001, 26, 119-124. [CrossRef]

166. Zalewska, A.; Głowacka, E.; Wyczółkowska, J.; Tchórzewski, H.; Narbutt, J.; Sysa-Jędrzejowska, A. Interleukin 6 and 8 levels in plasma and fibroblast cultures in psoriasis. Mediat. Inflamm. 2006, 2006, 081767. [CrossRef]

167. Villanova, F.; Di Meglio, P.; Nestle, F.O. Biomarkers in psoriasis and psoriatic arthritis. ARD 2013, 72, ii104-ii110. [CrossRef] [PubMed]

168. Lüthje, K.; Kallies, A.; Shimohakamada, Y.; Belz, G.T.; Light, A.; Tarlinton, D.M.; Nutt, S.L. The development and fate of follicular helper T cells defined by an IL-21 reporter mouse. Nat. Immunol. 2012, 13, 491-498. [CrossRef] [PubMed]

169. Wang, Y.; Wang, L.L.; Yang, H.Y.; Wang, F.F.; Zhang, X.X.; Bai, Y.P. Interleukin-21 is associated with the severity of psoriasis vulgaris through promoting $\mathrm{CD}^{+} \mathrm{T}$ cells to differentiate into Th17 cells. Am. J. Transl. Res. 2016, 8, 3188.

170. Shi, Y.; Chen, Z.; Zhao, Z.; Yu, Y.; Fan, H.; Xu, X.; Gu, J. IL-21 induces an imbalance of Th17/Treg cells in moderate-to-severe plaque psoriasis patients. Front. Immunol. 2019, 10, 1865. [CrossRef]

171. Nguyen, V.; Rus, H.; Chen, C.; Rus, V. CTL-promoting effects of IL-21 counteract murine lupus in the parent $\rightarrow$ F1 graft-versus-host disease model. J. Immunol. 2016, 196, 1529-1540. [CrossRef]

172. Cho, J.J.; Xu, Z.; Parthasarathy, U.; Drashansky, T.T.; Helm, E.Y.; Zuniga, A.N.; Lorentsen, K.J.; Mansouri, S.; Cho, J.Y.; Edelmann, M.J.; et al. Hectd3 promotes pathogenic Th17 lineage through Stat3 activation and Malt1 signaling in neuroinflammation. Nat. Commun. 2019, 10, 701. [CrossRef] 
173. Venken, K.; Jacques, P.; Mortier, C.; Labadia, M.E.; Decruy, T.; Coudenys, J.; Hoyt, K.; Wayne, A.; Hughes, R.; Turner, M.; et al. ROR $\gamma \mathrm{t}$ inhibition selectively targets IL-17 producing iNKT and $\gamma \delta$-T cells enriched in Spondyloarthritis patients. Nat. Commun. 2019, 10, 9. [CrossRef] [PubMed]

174. Liu, T.; Li, S.; Ying, S.; Tang, S.; Ding, Y.; Li, Y.; Qiao, J.; Fang, H. The IL-23/IL-17 pathway in inflammatory skin diseases: From bench to bedside. Front. Immunol. 2020, 11, 2971. [CrossRef] [PubMed]

175. Rutz, S.; Eidenschenk, C.; Ouyang, W. IL-22, not simply a Th17 cytokine. Immunol. Rev. 2013, 252, 116-132. [CrossRef] [PubMed]

176. Sa, S.M.; Valdez, P.A.; Wu, J.; Jung, K.; Zhong, F.; Hall, L.; Kasman, I.; Winer, J.; Modrusan, Z.; Danilenko, D.M.; et al. The effects of IL-20 subfamily cytokines on reconstituted human epidermis suggest potential roles in cutaneous innate defense and pathogenic adaptive immunity in psoriasis. J. Immunol. 2007, 178, 2229-2240. [CrossRef]

177. Sabat, R.; Ouyang, W.; Wolk, K. Therapeutic opportunities of the IL-22-IL-22R1 system. Nat. Rev. Drug Discov. 2014, 13, 21-38. [CrossRef]

178. Cordoro, K.M.; Hitraya-Low, M.; Taravati, K.; Sandoval, P.M.; Kim, E.; Sugarman, J.; Pauli, M.L.; Liao, W.; Rosenblum, M.D. Skin-infiltrating, interleukin-22-producing T cells differentiate pediatric psoriasis from adult psoriasis. JAAD 2017, 77, 417-424. [CrossRef]

179. Zhuang, L.; Ma, W.; Yan, J.; Zhong, H. Evaluation of the effects of IL-22 on the proliferation and differentiation of keratinocytes in vitro. Mol. Med. Rep. 2020, 22, 2715-2722. [CrossRef]

180. Nikamo, P.; Cheuk, S.; Lysell, J.; Enerbäck, C.; Bergh, K.; Landén, N.X.; Eidsmo, L.; Ståhle, M. Genetic variants of the IL22 promoter associate to onset of psoriasis before puberty and increased IL-22 production in T cells. J. Investig. Dermatol. 2014, 134, 1535-1541. [CrossRef]

181. Voglis, S.; Moos, S.; Kloos, L.; Wanke, F.; Zayoud, M.; Pelczar, P.; Giannou, A.D.; Pezer, S.; Albers, M.; Luessi, F.; et al. Regulation of IL-22BP in psoriasis. Sci. Rep. 2018, 8, 5085. [CrossRef]

182. Tsai, Y.C.; Tsai, T.F. Anti-interleukin and interleukin therapies for psoriasis: Current evidence and clinical usefulness. TAMD 2017, 9, 277-294. [CrossRef]

183. Nickoloff, B.J.; Nestle, F.O. Recent insights into the immunopathogenesis of psoriasis provide new therapeutic opportunities. $J$. Clin. Investig. 2004, 113, 166. [CrossRef]

184. Olson, J.L.; Courtney, R.J.; Rouhani, B.; Mandava, N.; Dinarello, C.A. Intravitreal anakinra inhibits choroidal neovascular membrane growth in a rat model. Ocul. Immunol. Inflamm. 2009, 17, 195-200. [CrossRef] [PubMed]

185. Nestle, F.O.; Conrad, C.; Tun-Kyi, A.; Homey, B.; Gombert, M.; Boyman, O.; Burg, G.; Liu, Y.J.; Gilliet, M. Plasmacytoid predendritic cells initiate psoriasis through interferon- $\alpha$ production. J. Exp. Med. 2005, 202, 135-143. [CrossRef] [PubMed] 